Article

\title{
Strengths and Limitations of UAV and Ground-based Structure from Motion Photogrammetry in a Gullied Savanna Catchment
}

\author{
Jack Koci ${ }^{{ }^{*}}$, Javier X. Leon ${ }^{1,2}$, Ben Jarihani ${ }^{1}$, Roy C. Sidle ${ }^{1}$, Scott N. Wilkinson ${ }^{3}$, Rebecca Bartley ${ }^{4}$ \\ 1 Sustainability Research Centre, University of the Sunshine Coast, 90 Sippy Downs Drive, Sippy Downs, \\ Queensland, Australia, 4556; jack.koci@research.usc.edu.au (J.K.); bjarihan@usc.edu.au (B.J.); \\ rsidle@usc.edu.au (R.C.S.) \\ 2 School of Science and Engineering, University of the Sunshine Coast; jleon@usc.edu.au (J.X.L.) \\ 3. Commonwealth Scientific and Industrial Research Organisation, Land and Water, GPO Box 1700, \\ Canberra, Australian Capital Territory; scott.wilkinson@csiro.au (S.N.W.) \\ 4. Commonwealth Scientific and Industrial Research Organisation, Land and Water, GPO Box 2583, Brisbane, \\ Queensland; rebecca.bartley@csiro.au (R.B) \\ *Correspondence: jack.koci@research.usc.edu.au; Tel: +61 754565973
}

\begin{abstract}
Structure from Motion with Multi-View Stereo photogrammetry (SfM) is increasingly utilised in geoscience investigations as a cost-effective method of acquiring high resolution (submeter) topographic data, but has not been thoroughly tested in gullied savanna systems. The aim of this study was to test the accuracy of topographic models derived from aerial (via an Unmanned Aerial Vehicle, 'UAV') and ground-based (via a handheld digital camera, 'Ground') SfM in modelling a hillslope gully system in dry-tropical savanna, and to assess the strengths and limitations of the approach at different scales. A UAV survey covered an entire hillslope gully system $\left(0.715 \mathrm{~km}^{2}\right)$, whereas a Ground survey covered a single gully within the broader system $(650$ $\mathrm{m}^{2}$ ). SfM topographic models, including Digital Surface Models (DSM) and dense point clouds, were compared against RTK-GPS point data and a pre-existing airborne LiDAR Digital Elevation Model (DEM). Results indicate UAV SfM can deliver topographic models with a resolution and accuracy suitable to define gully systems at a hillslope scale (e.g., $0.1 \mathrm{~m}$ resolution with $\sim 0.5-1.3 \mathrm{~m}$ elevation error), while ground-based SfM is more capable of quantifying gully morphology (e.g., $0.01 \mathrm{~m}$ resolution with $\sim 0.1 \mathrm{~m}$ elevation error). Key strengths of SfM for these applications include: the production of high resolution 3D topographic models and ortho-photo mosaics, low survey instrument costs (<\$AUD 3,000); and rapid survey time (4 and 2 hours for UAV and Ground survey respectively). Current limitations of SfM include: difficulties in reconstructing vegetated surfaces; uncertainty as to optimal survey and processing designs; and high computational demands. Overall, this study has demonstrated great potential for SfM to be used as a cost-effective tool to aid in the mapping, modelling and management of hillslope gully systems at different scales, in tropical savanna landscapes and elsewhere.
\end{abstract}

Keywords: digital elevation model; DEM; digital surface model; DSM; great barrier reef; gully erosion; multi-view stereo; point cloud; unmanned aerial vehicle

\section{Introduction}

Gully erosion is a globally significant land degradation process that has detrimental environmental, ecological and economic impacts across a range of landscape systems [1-7]. Effective management of gully erosion requires high resolution topographic information that can be used to accurately quantify the spatial distribution and density of gully systems, gully morphology and morphologic change, and the catchment characteristics that influence gully evolution [2,8-10]. Recent advances in remote sensing techniques have greatly improved our ability to collect high resolution topographic data at a range of scales [11-13]. Light Detection and Ranging (LiDAR), for example, has 
become a major source of digital terrain information [11,12,14,15], and can be deployed from both airborne (e.g., airborne laser scanning, ALS) and terrestrial (e.g., terrestrial laser scanning, TLS) platforms. A major limitation of LiDAR is the high instrument and survey costs [13]. Structure from Motion with Multi-View Stereo photogrammetry (hereafter referred to as SfM) is increasingly utilised as a cost-effective alternative method of rapidly acquiring very-high resolution (sub-meter) and hyper resolution (sub-centimeter) topographic data [13,16-19].

SfM allows the creation of three-dimensional (3D) topographic models from a set of conventional digital photographs. In addition to topographic data, SfM also produces very high resolution orthophoto mosaics, providing a wealth of information for use in physical geography [13]. Over the past 10 years, SfM has been applied in a variety of geoscience investigations, including but not limited to; glaciology [20,21]; landslides [22,23]; volcanology [17,24]; structural geology [25]; fluvial morphology and flood reconstruction [26-29]; coastal morphology and coral reef studies [30-34]; and soil microtopography [35-37]. SfM is also increasingly utilised in gully studies, with work conducted in: Spain [38-41]; the Iberian Peninsula [18]; Italy [42]; Morocco [43-45]; the European Loess Belt [46]; upland sites across the UK [47]; California [48] and Iowa [49,50] in the United States; Northern Ethiopia [46,51]; and China [52-54]. These studies have generally found SfM to be of comparable accuracy to LiDAR systems, demonstrating great potential for it to be used in geomorphic investigations. Yet, the studies have also documented some important challenges of the methodology, which may limit its application. Further testing of the accuracy of SfM topographic models in different landscapes and geomorphic settings is therefore needed.

Currently, no studies have applied SfM to assess gully erosion in tropical savanna landscapes. Tropical savannas are particularly susceptible to gully erosion $[9,55,56]$, but compared to temperate landscapes, have received relatively little attention [3,56,57]. In this environment, accurately surveying gullies is challenging due to the complex spatial arrangement and distribution of vegetation, complex gully morphologic features (e.g., overhangs, undercuts, steep walls), and the large geographic extent in which gullies occur [15]. Gully erosion is a particularly significant issue in the grazed dry-tropical savanna catchments tributary to the Great Barrier Reef (GBR), Australia [5760]. In these catchments, more than $80,000 \mathrm{~km}$ of gully features have been identified [61], primarily on land in beef cattle production, which occupies about $75 \%$ of the total GBR catchment area $(\sim 423,000$ $\mathrm{km}^{2}$ ) [62]. Increasing evidence suggests gully erosion on these grazing lands is the dominant source of sediments and particulate nutrients (sorbed onto sediments) to coastal waters in the region [59,6368]. High loads of sediments and nutrients in coastal waterways are believed to be major contributing factors to the declining health of the coral reef ecosystem [58,59,69]. Gully erosion on grazed savanna landscapes is therefore a priority for management intervention [59,60,70,71].

In the GBR catchments, predictive models which relate gully density to landscape factors (e.g., geology, soil, topography, vegetation, land use) and climate have been used to quantify the extent of gully erosion at both local and regional scales [72,73]. The outputs of these models have then been used as inputs to broad scale catchment sediment budget models [Sediment River Network Model, $74,75,76]$, to identify primary erosion processes, estimate end-of-catchment sediment loads, and inform management interventions [71,77]. A key limitation of this approach has been a lack of high resolution topographic data with which to accurately quantify the extent of gully systems across the landscape $[76,78,79]$. Further, few studies have quantitatively measured gully morphology and morphologic change $[56,57,80,81]$, leading to uncertainty about the volume and mass of sediment fractions delivered to the stream network from gully erosion [76]. Finally, understanding of the key landscape factors and processes controlling gully erosion in this environment remains limited [57,58,81-83]. Yet, this information is critical for prioritising gully erosion hotspots, understanding gully erosion processes and dynamics, and for designing, monitoring and evaluating gully remediation activities [1,2]. Addressing such data and knowledge gaps requires the utilization of a range of methods at various spatial and temporal scales $[3,15,58]$. This study tests the accuracy of topographic models derived from aerial (via an Unmanned Aerial Vehicle, 'UAV') and ground-based (via a handheld digital camera) SfM in modelling a hillslope gully system located in a grazed dry- 
tropical savanna catchment tributary to the GBR, and assesses the strengths and limitations of the approach at different scales.

\section{Materials and Methods}

\subsection{Study site}

The study site is located within the Weany Creek sub-catchment $\left(13.6 \mathrm{~km}^{2}\right)$, within the Upper Burdekin Catchment $\left(\sim 36,000 \mathrm{~km}^{2}\right)$, and part of the Burdekin River Basin $\left(130,000 \mathrm{~km}^{2}\right)$, which drains to the GBR in northeast Australia (Figure 1). The area has granodiorite lithology [84,85] and is dominated by chromosol soil, a sandy clay loam, known locally as red goldfields soil. Chromosol soils, which cover approximately $12 \%$ of the Burdekin River basin, contain numerous gullies and are therefore a priority for management intervention [86]. The terrain is dissected by many drainage depressions, although relief and slope gradients are low (median gradient is 2.3\% [87]). The climate is dry-tropical with two distinct seasons; a summer wet season between October and March, and a dry season between April and September [88]. The mean-annual rainfall (1900-2012) is $686 \mathrm{~mm} \mathrm{y}^{-1}$, but exhibits high interannual variability linked to the phase of the Southern Oscillation, with drought conditions coinciding with El Niño/Southern Oscillation (ENSO), and wetter periods accompanying anti-ENSO (La Niña) events [89,90]. Vegetation is generally characterised by a discontinuous upper stratum of Eucalyptus spp. and a more continuous understory of annual and perennial grasses, forbs and small shrubs [91] (Figure 2, inset c). Vegetation grows rapidly during the wet season, followed by a period of desiccation during the dry season [92-94]. Cattle grazing commenced in the area after 1850 and remains the dominant land use today.

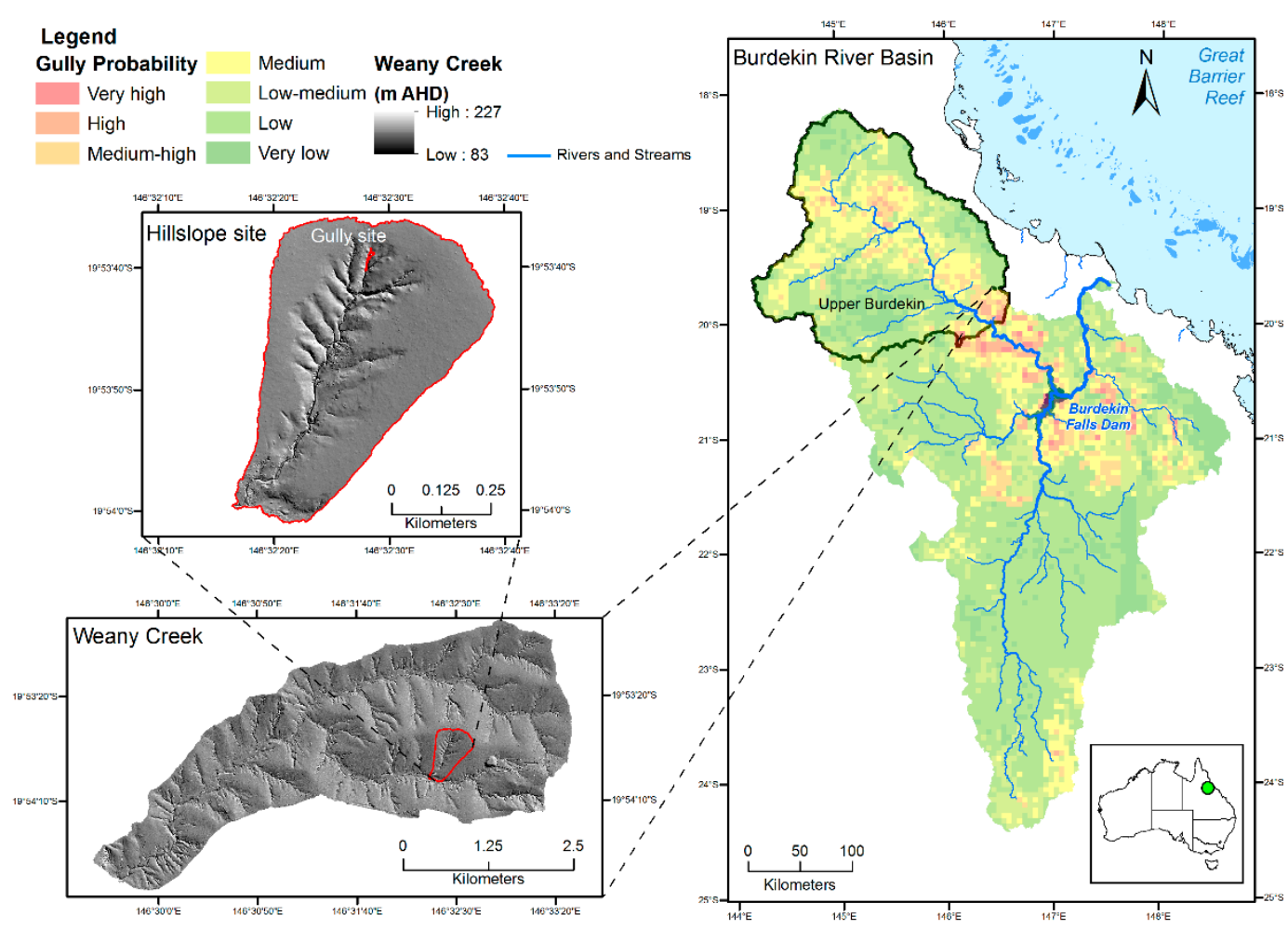

Figure 1. Map showing the location of the study site within the Weany Creek sub-catchment, within the Upper Burdekin catchment and part of the Burdekin River Basin. The gully probability mapping is reproduced from Gilad et al. [86] and shows high to very high probability of gullies in the Upper Burdekin catchment. The Weany Creek DEM and the Hillslope DEM are derived from airborne LiDAR captured in 2013, outlined in Tindall et al. [79].

Within the Weany Creek sub-catchment, measurements were focused at two scales: a hillslope scale $\left(0.715 \mathrm{~km}^{2}\right)$, surveyed via an UAV; and a gully scale $\left(650 \mathrm{~m}^{2}\right)$, surveyed via a hand-held digital 
camera, with images captured from ground-level, 'Ground' (Figure 2). The hillslope site was selected as it contains a diversity of gully features and has ground cover considered representative of the Weany Creek sub-catchment. The gully site was selected as it has been previously studied $[57,95]$ and is actively eroding.

The gully site contains a $\mathrm{V}$ - shaped gully with steep sidewalls $\left(45-90^{\circ}\right)$, a narrow gully floor $(0.2$ $-1 \mathrm{~m}$ wide) and two distinct headcuts (Figure 3 ). The headcuts are slightly over-hanging in the upper $0.5-1 \mathrm{~m}$ of the incision profile, with total headcut heights ranging from $1-1.5 \mathrm{~m}$. Evidence of mass wasting at the headcuts is clearly visible, with scouring around the base of the head wall, and large sediment deposits on the gully floor. Rill fluting occurs along portions of gully sides. Weathered bedrock is exposed in sections of gully wall, typically in the lower $0.5 \mathrm{~m}$ of the profile. At the time of the Ground survey (October 2016), grass (predominantly Indian Couch (Bothriochloa pertusa) and woody legumes (Stylosanthes spp.); height of $\sim 30-50 \mathrm{~cm}$ ) occupied much of the area along the gully edge and in some sections of the more gently sloping gully wall, obscuring the bare soil. Leaves, bark and woody debris also partially covered the ground. Grass was not present in the gully floor. Thicker pockets of low-lying shrubs ( $1 \mathrm{~m}$ tall $\times 1 \mathrm{~m}$ wide) occupied some sections of gully edge and walls.

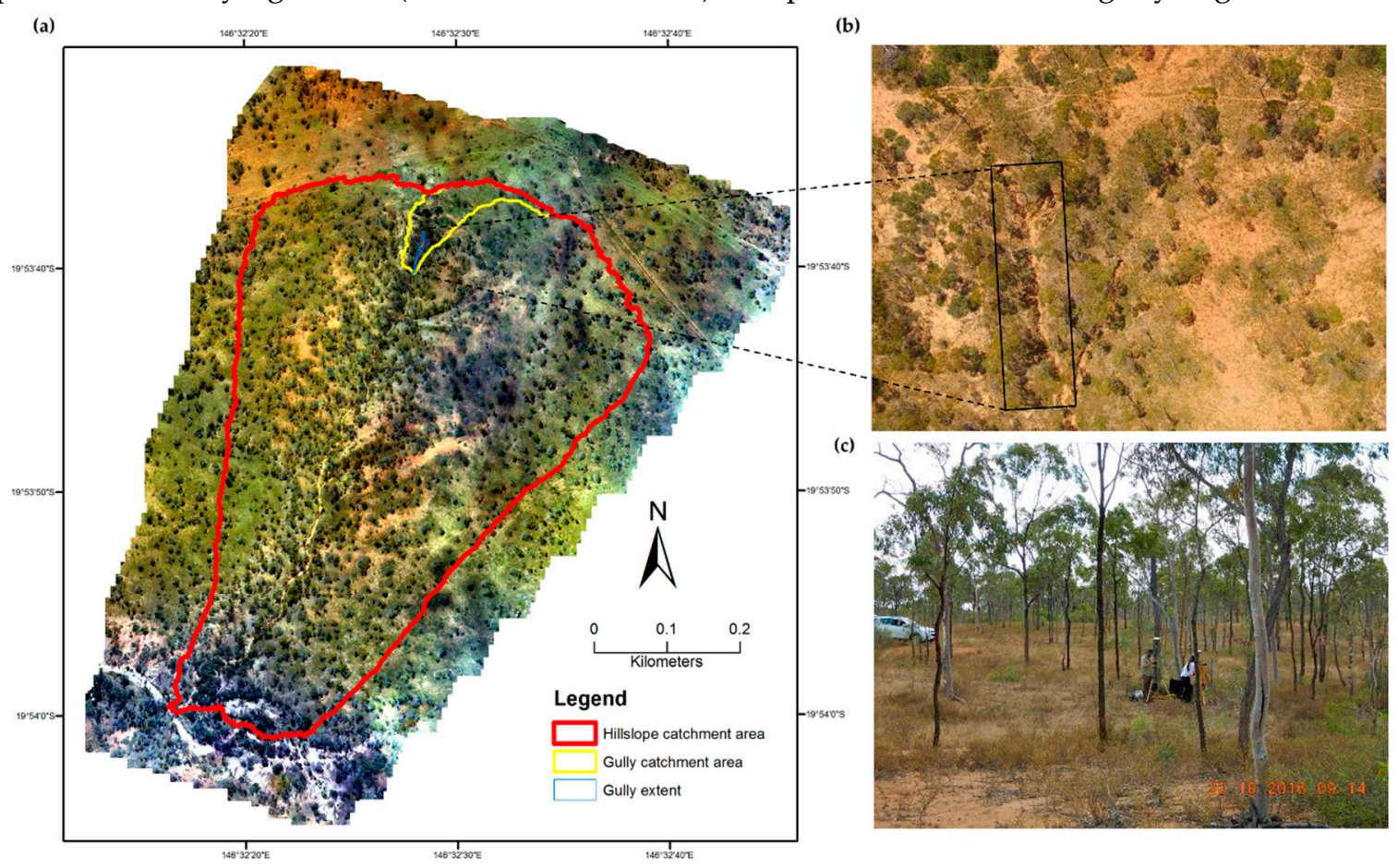

Figure 2. (a) Map showing the catchment area of the hillslope site and the gully site, and the gully extent. Background map is a UAV ortho-photo mosaic of the hillslope site. (b) UAV image of the gully site. (c) Ground image of typical savanna vegetation in the contributing area of the gully site. 


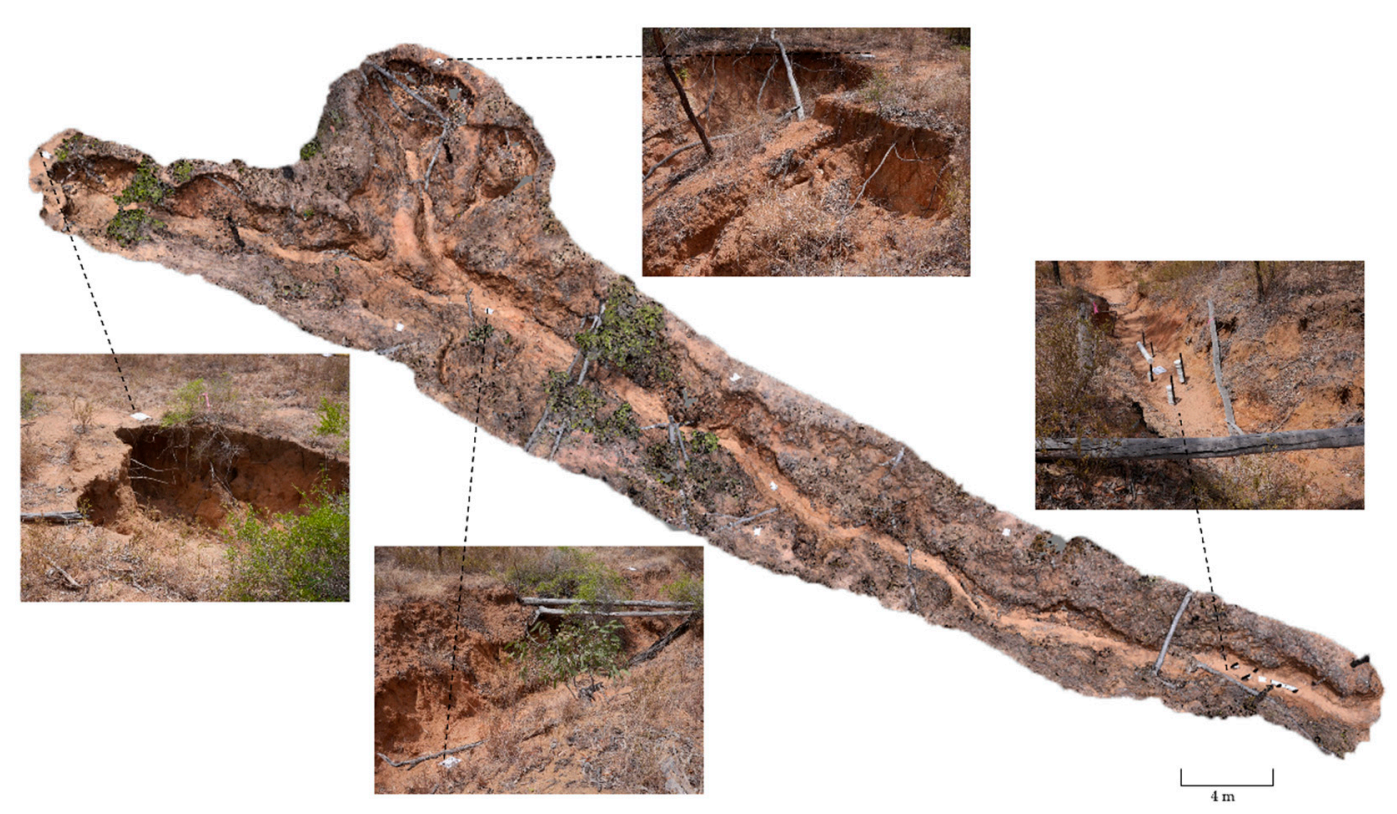

Figure 3. Ground Digital Surface Model (DSM) of the gully site with inset photographs at specific points, used in SfM reconstruction. Note, the scale bar does not relate to inset photographs.

\subsection{Datasets}

\subsubsection{LiDAR}

The airborne LiDAR data, covering the area around and including the hillslope site, was acquired in 2013 as part of a larger airborne LiDAR survey campaign by the Queensland Department of Science, Information Technology, Innovation and the Arts [79]. The sensors were configured to sample the gully environment with an average pulse density of $4.2 \mathrm{~m}^{2}$ (each pulse recorded up to 5 returns) and an overlap of $50 \%$ between flight runs to minimise the impact of occlusion from variable terrain and vegetation. This resulted in an average of 8 pulses per $\mathrm{m}^{2}$. DEM surfaces were interpolated using the natural neighbor algorithm [96] at a spatial resolution of $0.5 \mathrm{~m}$ using the LiDAR returns classified as ground. The DEM has a reported elevation accuracy of $0.2 \mathrm{~m} \pm 0.1 \mathrm{~m}$. More detail on LiDAR capture specifications, DEM generation and accuracy are given in Tindall et al., [79].

\subsubsection{UAV and Ground survey}

In August 2016, the UAV survey of the hillslope site was conducted using a DJI Phantom 3 Professional Drone [97], fitted with a DJI FC300X camera and a DJI $3.61 \mathrm{~mm}$ lens (20 mm focal length on a $35 \mathrm{~mm}$ camera equivalent). The flying mission was planned using the Map Pilot App by Maps Made Easy (https://www.mapsmadeeasy.com/). Seven Ground Control Points (GCPs) were distributed across the study area (Figure 4a). The GCPs consisted of a $1.2 \times 1.2 \mathrm{~m}$ black and white "iron cross" vinyl marker. The GCPs and an additional 341 random validation points, were surveyed using a CHC X91 Real Time Kinematic GPS (RTK GPS) receiver. The RTK GPS had a mean horizontal error of $0.014 \mathrm{~m}$ (standard deviation, SD of $0.004 \mathrm{~m}$ ), and a mean vertical error of $0.030 \mathrm{~m}$ (SD of 0.010 $\mathrm{m})$. The UAV survey took approximately 4 hours. Further details about the UAV survey are outlined in Table 1.

In October 2016, the Ground survey of the gully site was conducted using a Panasonic GH3 digital camera, fitted with a Panasonic Lumix G 20 mm F1.7 II ASPH prime lens, set to P-mode (i.e., automatic mode with no flash). Ten GCPs were distributed on the ground surface throughout the gully system along the gully walls and floor (Figure $4 b$ ). The GCPs consisted of a laminated A4 page with 4 coded circular targets, produced using the 'Print Markers' tool within AgiSoft PhotoScan Professional V1.3 (PhotoScan) [98]. The GCPs and an additional 134 random validation points were surveyed using an Ashtech Magellan Promark 500 RTK GPS. The RTK GPS had a mean horizontal error of $0.018 \mathrm{~m}$ (SD of $0.003 \mathrm{~m}$ ) and a mean vertical error of $0.026 \mathrm{~m}$ (SD of $0.004 \mathrm{~m}$ ). 
Initial attempts at the Ground survey, involving significantly fewer photos and a non-systematic approach to image capture (e.g. random path of photographer, images captured non-consecutively) resulted in poor surface reconstruction. Here we outline the method of image capture found to produce the best surface reconstruction (Figure 4c,d). The photographer started at the gully head approximately $3 \mathrm{~m}$ from the gully edge, and worked their way along the gully perimeter, capturing one image approximately every meter, focusing obliquely on the opposite bank toward the downstream end. Upon reaching the gully outlet, the photographer followed a similar path back toward the gully head, again focusing obliquely on the opposite bank, but this time toward the upstream end. Upon reaching the gully head (i.e., the starting point), the photographer moved to the gully edge and repeated the process. Once images were captured on both sides of the gully periphery, the photographer then captured images through the center of the gully, walking along the gully bed. Images were captured along three lines: one line focused directly downstream and upstream; and two lines focused obliquely toward the left and right bank respectively, upstream and downstream. Following guidance provided by Smith et al. [13], the photographer tried to achieve full $360^{\circ}$ coverage of gully features with a high degree of overlap between images; avoided large angular changes of $>25-30^{\circ}$ between adjacent camera locations and large jumps in scale; and minimized the interval between images to reduce the effect of changes in lighting and shadow conditions. The gully took approximately two hours to survey.

Table 1. UAV and Ground survey details.

\begin{tabular}{|c|c|c|c|c|c|c|c|c|}
\hline Survey & $\begin{array}{l}\text { Image } \\
\text { resolution } \\
\text { (MP) }\end{array}$ & $\begin{array}{l}\text { Altitude } \\
\text { of } \\
\text { image } \\
\text { capture } \\
\text { (m) }\end{array}$ & $\begin{array}{c}\text { Forward } \\
\text { overlap } \\
(\%)\end{array}$ & $\begin{array}{c}\text { Side } \\
\text { overlap } \\
(\%)\end{array}$ & $\begin{array}{c}\text { Image } \\
\text { overlap } \\
\text { (number } \\
\text { of } \\
\text { images) }\end{array}$ & $\begin{array}{l}\text { No. of } \\
\text { images }\end{array}$ & $\begin{array}{c}\text { Area } \\
\text { covered } \\
\left(\mathrm{m}^{2}\right)\end{array}$ & $\begin{array}{l}\text { Ground } \\
\text { resolution } \\
\left(\mathrm{cm} \mathrm{pix}^{-1}\right)\end{array}$ \\
\hline UAV & 12 & 90 & 80 & 75 & $>9$ & 938 & 715,000 & 3.31 \\
\hline Ground & 8 & 1.5 & - & - & $>9$ & 1747 & 650 & 0.129 \\
\hline
\end{tabular}

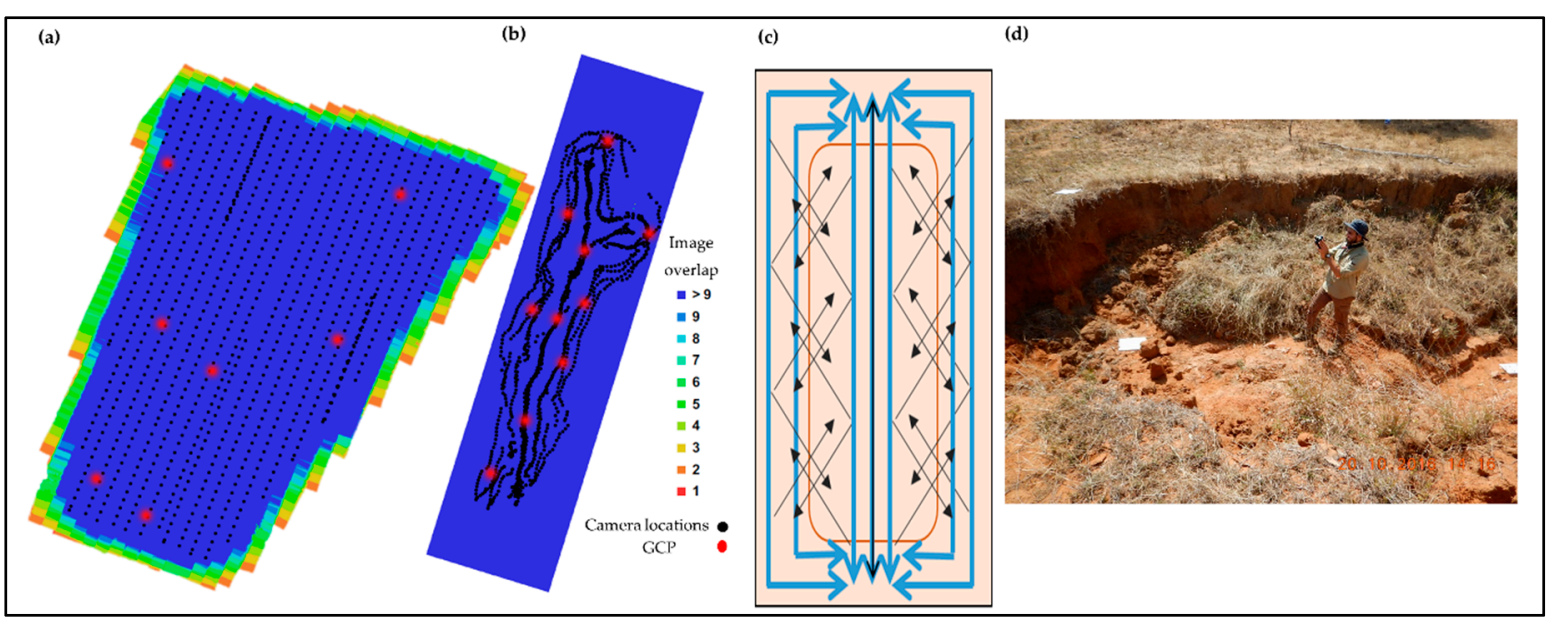

Figure 4. Camera and GCP locations and image overlap of (a) UAV survey; and (b) Ground survey. (c) Theoretical path of photographer (blue arrows) and direction of image capture (black arrows) during Ground survey. The brown line diagrammatically defines the gully edge. (d) Photographer during a Ground survey.

\subsection{Data post-processing}

\subsubsection{SfM workflow, 3D model, and ortho-photo generation}

Agisoft PhotoScan software was used to implement the SfM workflow. Details of the processing parameters and processing times are provided in Supplementary Table 1. The SfM workflow, described in detail elsewhere [13,19], can be summarized into three main steps. The first step 
involves: (i) the identification and matching of features in a set of images, utilising an algorithm based on the scale invariant feature transform (SIFT) object recognition system [99]; and (ii) the implementation of bundle adjustment algorithms to estimate the 3D geometry (or structure) of a scene, as well as the internal and external camera orientation parameters [98], producing a sparse, unscaled 3D point cloud in arbitrary units. The second step involves: (i) a linear similarity transformation to scale and georeference the point cloud, utilising reference coordinates of GCPs distributed throughout the study site; and (ii) point cloud optimization, a process in which camera parameters and 3D points are adjusted to minimise the sum of the reprojection error and the georeferencing error [98]. The final step involves the implementation of multi-view stereo (MVS) image matching algorithms to build a dense 3D point cloud. A fourth step can be added to the SfM workflow to generate textured 3D models and ortho-photo mosaics derived from the dense point clouds. In this study, PhotoScan processing ran on a computer which carried an 8GB NVIDIA Quadro K5200 graphics card, two Intel Xeon CPU E5 K5200 v2 @2.5 GHZ processors, and 128 GB RAM. Total processing time for the UAV and Ground survey data were $\sim 31$ and $\sim 110$ hours respectively.

\subsubsection{Digital Surface Model (DSM) generation}

DSMs, derived from the dense point clouds, were generated using the 'rasterize' tool in CloudCompare (v2.8) [100]. The minimum elevation point at each pixel was used to model the terrain surface, as it has the greatest chance to represent the surface within vegetated areas [26], in the absence of vegetation filtering of the point cloud. The UAV DSM was generated at $0.1 \mathrm{~m}$ pixel size, whereas the Ground DSM was generated at $0.01 \mathrm{~m}$ pixel size.

\subsubsection{Conversion to the Australian Height Datum}

The airborne LiDAR DEM elevation values were referenced to the Australian Height Datum (AHD), whereas the RTK validation points and UAV and Ground DSMs had elevation values referenced to the ellipsoid GDA94. To allow comparison among the datasets, the elevation values of the DSMs and RTK validation points were converted to AHD, using the AusGeoid09 transformation (http://www.ga.gov.au/ausgeoid/nvalcomp.jsp), prior to accuracy assessment.

\subsubsection{Elevation accuracy of SfM topographic models}

The elevation accuracy of the SfM topographic models was evaluated using point-to-raster, point-to-point, and raster-to-raster comparisons. In the point-to-raster comparison, elevation values were extracted from the DSM and compared to concordant RTK validation points. In the point-topoint comparison, elevation values were extracted from the dense point cloud (prior to rasterization) and compared to concordant RTK validation points, using the 'compute cloud/cloud distance' tool in CloudCompare. Point-to-point comparison is useful in topographically complex environments [101] such as gullies, where steep sides and overhangs are common [46], as a given set of $\mathrm{x}$ and $\mathrm{y}$ coordinates can have multiple $\mathrm{z}$ values [42,102]. In the raster-to-raster comparison, the UAV DSM was subtracted from the airborne LiDAR DEM, allowing examination of the spatial distribution of error. Here we assume the airborne LiDAR DEM was more accurate the UAV DSM.

Elevation accuracy is evaluated for: (i) all validation points (excluding GCPs) within the hillslope site; (ii) all validation points (excluding GCPs) within the gully site; and (iii) individual cross-sections across the gully site. Accuracy metrics include: root mean square error (RMSE), mean absolute error (MAE); mean error (ME); and standard deviation of error (STDE) [102].

A vertical shift was applied to points extracted from the UAV DSM. The vertical shift was based on a linear regression between the RTK validation points and the corresponding points extracted from the UAV DSM, according to the equation:

$$
\mathrm{Y}=1.0342 \mathrm{x}-8.6882\left(\mathrm{r}^{2}=0.976\right)
$$

where $\mathrm{Y}=$ elevation value after linear regression; and $\mathrm{x}=$ elevation value prior to linear regression. This dataset is referred to as UAV DSM Shift. Error is evaluated before and after the shift was applied. 


\section{Results}

At the hillslope scale $\left(0.715 \mathrm{~km}^{2}\right)$, the UAV DSM has relatively large elevation errors $(\mathrm{RMSE}=$ $1.307 \mathrm{~m}, \mathrm{MAE}=1.220 \mathrm{~m}$, Table 2), despite the very low georeferencing error of the GCPs (Table 3). The distribution of errors is negatively skewed (Figure 5a), with about 91\% of the error between 0.01 and $2 \mathrm{~m}$ (i.e., lower than the RTK validation points). Comparison of the UAV DSM to the airborne LiDAR DEM reveals systematic error across the hillslope (Figure 6a), which appears to be related to the location of GCPs. In the upper half of the hillslope, and through the centre of the lower hillslope, the UAV DSM is generally lower than the LiDAR DEM (0.1 - $2 \mathrm{~m}$ difference). The magnitude of difference increases towards the centre of the upper hillslope, with increasing distance from GCPs. In contrast, the outer edges of the upper hillslope, and middle and outer sections of the lower hillslope, are generally higher than the LiDAR DEM (0.1 - $2 \mathrm{~m}$ difference). These results suggest the number and distribution of GCPs across the large survey area may have been insufficient to properly parameterize the SfM model during bundle adjustment, resulting in model deformation.

Applying a vertical shift to the elevation values of points extracted from the UAV DSM reduces the skewness of the error distribution (Figure 5b) and significantly improves overall error (Table 2). At the hillslope scale, UAV DSM elevation error is reduced to $0.550 \mathrm{~m}$, while at the individual gully scale, error is reduced to $0.404 \mathrm{~m}$.

Table 2. Summary of elevation errors in the comparison of RTK validation points and UAV and Ground DSMs

\begin{tabular}{|c|c|c|c|c|c|c|c|c|c|c|c|}
\hline Site & $\begin{array}{l}\text { \# RTK } \\
\text { points } \\
\text { (UAV) }\end{array}$ & $\begin{array}{c}\text { \# RTK } \\
\text { points } \\
\text { (Ground) }\end{array}$ & $\begin{array}{l}\text { UAV } \\
\text { DSM }\end{array}$ & $\begin{array}{l}\text { RMSE } \\
\text { UAV } \\
\text { DSM } \\
\text { Shift }\end{array}$ & $\begin{array}{c}\text { Ground } \\
\text { DSM }\end{array}$ & $\begin{array}{l}\text { UAV } \\
\text { DSM }\end{array}$ & $\begin{array}{l}\text { MAE } \\
\text { UAV } \\
\text { DSM } \\
\text { Shift }\end{array}$ & $\begin{array}{c}\text { Ground } \\
\text { DSM }\end{array}$ & $\begin{array}{l}\text { UAV } \\
\text { DSM }\end{array}$ & $\begin{array}{c}\text { ME } \\
\text { UAV } \\
\text { DSM } \\
\text { Shift }\end{array}$ & $\begin{array}{c}\text { Ground } \\
\text { DSM }\end{array}$ \\
\hline XS1 & 21 & 15 & 1.522 & 0.367 & 0.059 & 1.519 & 0.347 & 0.048 & 1.519 & 0.347 & -0.047 \\
\hline XS2 & 19 & 11 & 1.568 & 0.440 & 0.076 & 1.556 & 0.384 & 0.050 & 1.556 & 0.381 & -0.007 \\
\hline XS3 & 20 & 12 & 1.466 & 0.335 & 0.073 & 1.455 & 0.277 & 0.059 & 1.455 & 0.268 & -0.030 \\
\hline XS4 & 19 & 11 & 1.439 & 0.288 & 0.073 & 1.432 & 0.241 & 0.068 & 1.432 & 0.240 & -0.068 \\
\hline XS5 & 21 & 12 & 1.403 & 0.279 & 0.093 & 1.393 & 0.225 & 0.082 & 1.393 & 0.193 & -0.082 \\
\hline Gully & 151 & 151 & 1.538 & 0.404 & 0.092 & 1.527 & 0.362 & 0.052 & 1.527 & 0.343 & -0.014 \\
\hline Hillslope & 471 & 151 & 1.307 & 0.550 & NA & 1.220 & 0.422 & NA & 1.180 & -0.011 & NA \\
\hline
\end{tabular}

Note, $\#=$ number of. SDE not shown. XS refers to cross-sections. Cross-section locations shown in Figure 7a.

Table 3. Georeferencing error (RMSE) of GCPs for the UAV and Ground Survey (m)

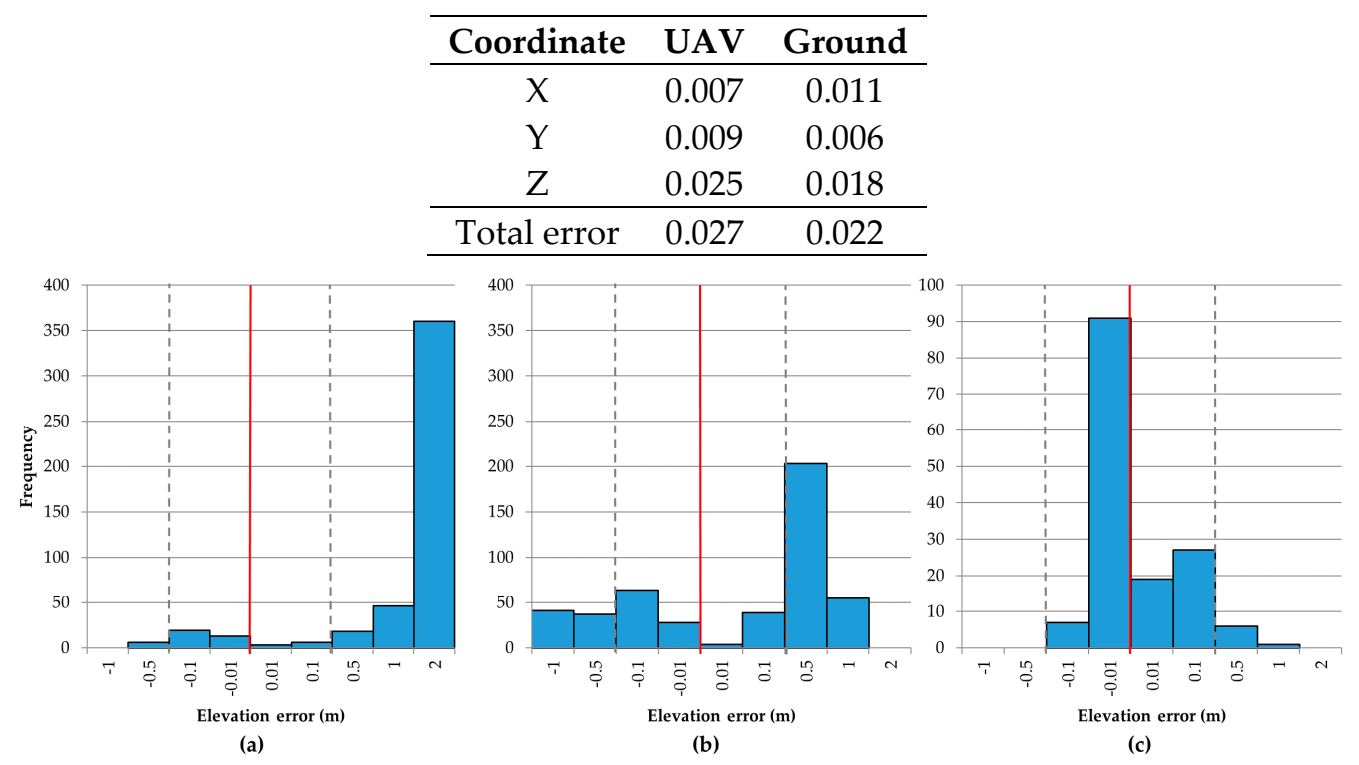

Figure 5. Distribution of elevation error between RTK validation points and: (a) UAV DSM (before vertical shift); (b) UAV DSM (after vertical shift); and (c) Ground DSM. Red line indicates $0 \mathrm{~m}$, dashed lines indicate \pm $0.1 \mathrm{~m}$. 


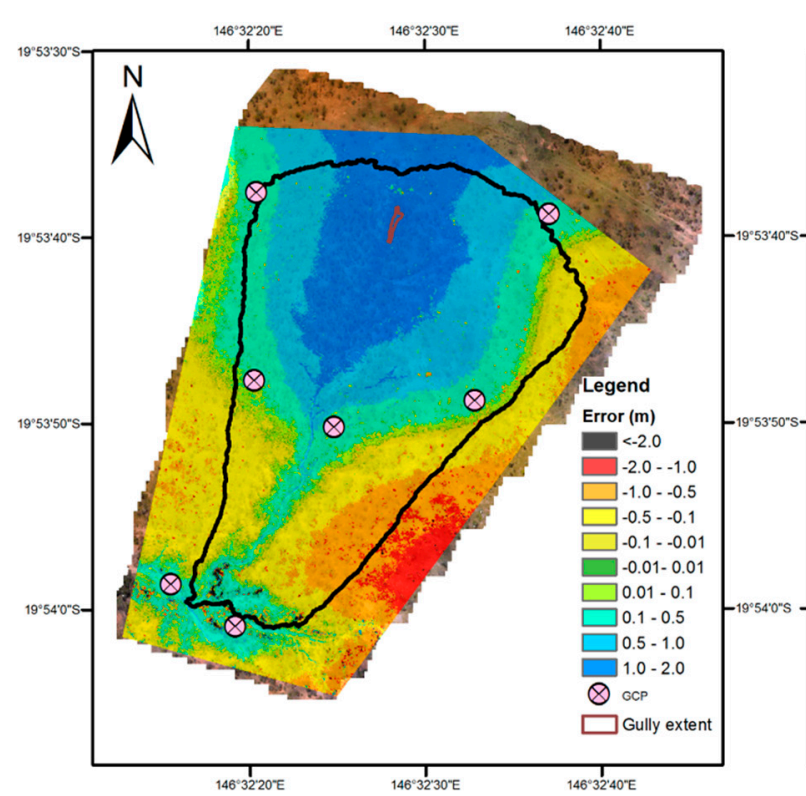

(a)

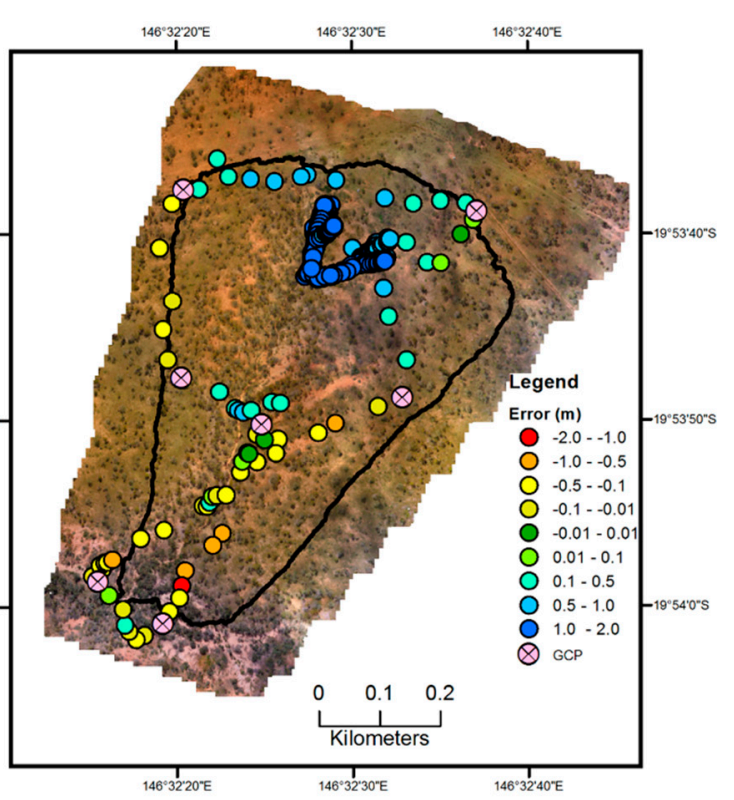

(b)

Figure 6. (a) Map showing the difference between the airborne LiDAR DEM and the UAV DSM across the hillslope site. (b) Difference between RTK validation points and points extracted from UAV DSM.

Comparison of the UAV dense point cloud to the RTK validation dataset reduced the elevation error at the hillslope scale by about $0.3 \mathrm{~m}$ (Table 4), suggesting some error may have also been introduced during point cloud rasterization. One explanation for this is that an individual point is more likely to represent the true ground surface than a point extracted from a rasterized cell, which may be affected by vegetation. Vegetation is estimated to cover $\sim 80-90 \%$ of the survey area and includes irregularly distributed grass, shrubs and trees. Visual inspection of the spatial variability of error across the ortho-photo mosaics (Figure $6 \mathrm{~b}$ ) does not reveal any distinct patterns related to vegetation effects on error; high errors are observed in both bare and vegetated patches. It is possible the high degree of vegetation cover at the time of the survey may have introduced broad-scale error into the topographic model during image processing that could mask the vegetation effect at smaller scales.

Table 4. Summary of the elevation errors in the comparison of RTK validation points and UAV and Ground dense point clouds

\begin{tabular}{|c|c|c|c|c|c|c|c|c|c|}
\hline \multirow[b]{2}{*}{ Site } & \multirow{2}{*}{$\begin{array}{l}\text { \# val. } \\
\text { points } \\
\text { (UAV) }\end{array}$} & \multicolumn{2}{|c|}{ RMSE (m) } & \multicolumn{2}{|c|}{ MAE (m) } & \multicolumn{2}{|c|}{ ME (m) } & \multicolumn{2}{|c|}{ SDE (m) } \\
\hline & & UAV & Ground & UAV & Ground & UAV & Ground & UAV & Ground \\
\hline Gully & 151 & 0.915 & 0.039 & 0.844 & 0.031 & 0.840 & -0.020 & 0.364 & 0.034 \\
\hline Hillslope & 471 & 0.959 & NA & 0.870 & NA & 0.832 & NA & 0.476 & NA \\
\hline
\end{tabular}

At the individual gully scale $\left(650 \mathrm{~m}^{2}\right)$, the Ground DSM has a much lower elevation error (RMSE of $0.092 \mathrm{~m}$; MAE of $0.052 \mathrm{~m}$, Table 2) than the UAV DSM. Similar to the UAV DSM, comparison of the Ground dense point cloud with the RTK validation dataset reduced the elevation error to about $0.04 \mathrm{~m}$ (Table 4), suggesting the dense point cloud better represents the complex 3D gully geometry than the DSM. Ninety five percent of Ground validation points have an error of between $-0.1 \mathrm{~m}$ and $0.1 \mathrm{~m}$ (Figure 5c), with no discernible error pattern related to landscape position (Figure 7a). Examination of individual cross-sections across the gully site clearly show a vertical offset of around $1.5 \mathrm{~m}$ between points extracted from the UAV DSM and the RTK validation points (Figure $7 \mathrm{~b}, \mathrm{c}$ ). This offset is reduced to about $0.5 \mathrm{~m}$ after the vertical shift is applied. The amount of offset varies depending on position in the profile, being greater in the gully bed and smaller on the gully walls. Despite the vertical offset, the UAV DSM broadly follows the shape of the RTK cross-sectional profile. The Ground DSM cross-sectional profiles closely follow the shape of the RTK profiles and therefore 
provide the best representation of gully shape. For each DSM, there was some variation in error metrics among cross-sectional profiles (e.g., RMSE values varied by up to $37 \%$, Table 2), likely due to the small number of validation points in each cross section. Therefore, error estimates over the entire gully system can be regarded as more reliable than error estimates for individual cross-sections.
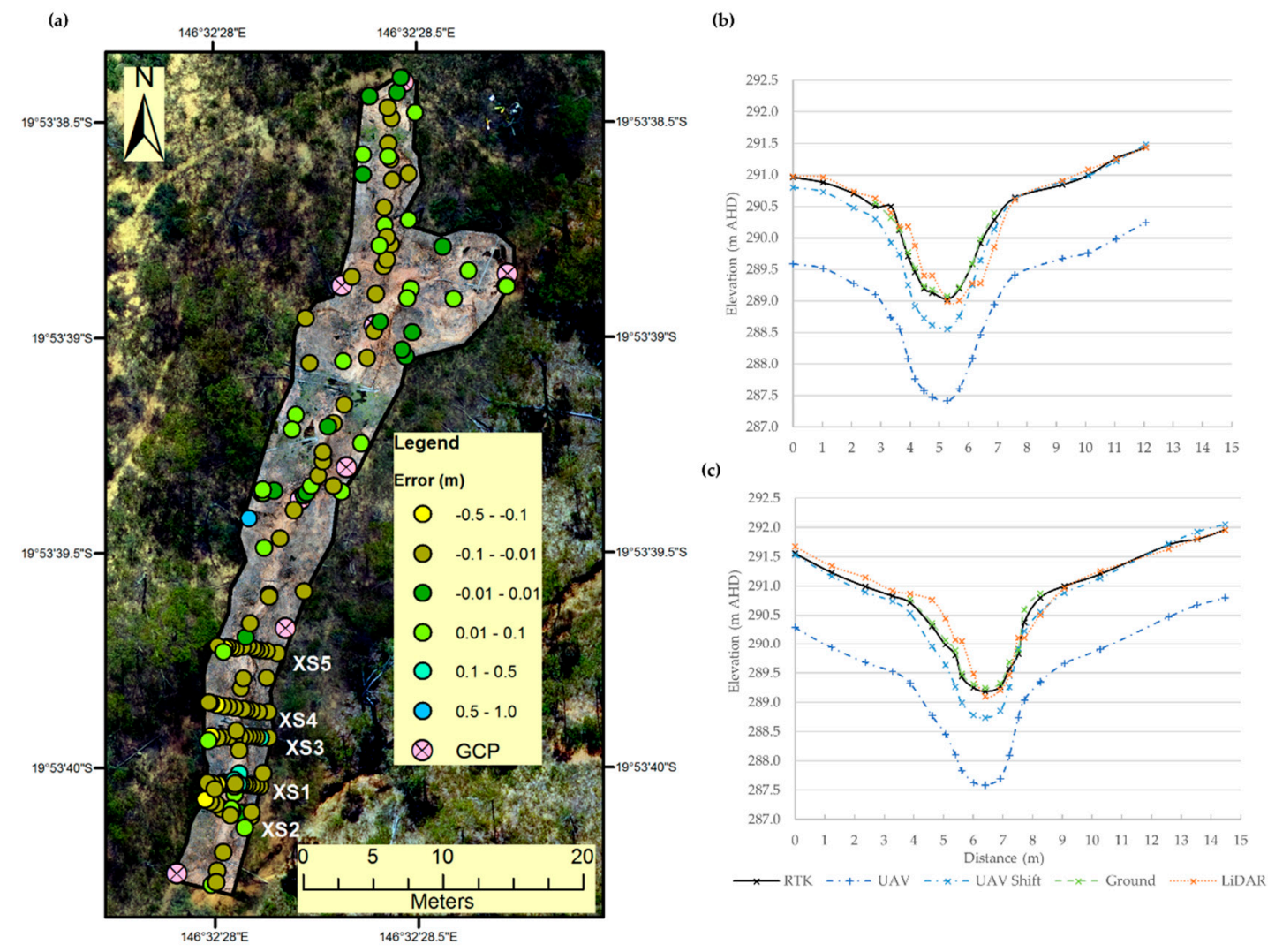

Figure 7. (a) Map showing the difference in elevation between RTK validation points and points extracted from the Ground DSM. XS refers to cross-section locations. (b) Comparison of cross-sectional profile between different survey platforms at XS3; and (c) XS5. Note, the Ground DSMs are spatially constrained and do not represent the complete cross-sectional profile.

\section{Discussion}

Here we evaluate the strengths and limitations of UAV and Ground SfM in modelling hillslope gully systems in tropical savanna. The strengths, limitations and opportunities, together with a comparison of the time and resource requirements of each approach, are summarized in Table 5.

\section{1 Strengths}

\subsubsection{Resolution and accuracy}

Results from our study indicate UAV SfM can deliver topographic models with a resolution and accuracy suitable to define gully systems at a hillslope scale (e.g. $0.1 \mathrm{~m}$ resolution with $\sim 0.5-1.3 \mathrm{~m}$ elevation error), while Ground SfM is more suitable for quantifying gully morphology at an individual gully scale (e.g. $0.01 \mathrm{~m}$ resolution with $\sim 0.1 \mathrm{~m}$ elevation error). These results are in line with other studies that have used aerial platforms to capture images across large areas in complex terrain (RMSE values ranging from $\sim 0.05 \mathrm{~m}$ to $\sim 1 \mathrm{~m}$ [18,36,47,101-103]), and ground-based approaches to model gully systems (RMSE values ranging from $0.025 \mathrm{~m}$ to $0.155 \mathrm{~m}$ [40$42,46,47,49,104,105])$. While the overall elevation errors of the UAV topographic models were large relative to a pre-existing airborne LiDAR dataset and RTK validation points, cross-sectional analysis revealed a vertical offset which, when corrected, substantially reduced elevation error to levels 
comparable to airborne LiDAR. The elevation errors of the Ground topographic models were substantially lower than those derived from UAV, and are similar to those reported by recent TLS surveys of gully systems in the region [errors of $\sim 0.05 \mathrm{~m}, 15,106]$. While further work is needed to ascertain survey repeatability and the ability to detect geomorphic change $[15,50,80,106]$, our results suggest there is great potential for both UAV and Ground SfM to deliver high resolution topographic information in gullied savanna catchments.

\subsubsection{High resolution ortho-photo mosaics and 3D models}

High resolution ortho-photo mosaics and 3D models produced as part of the SfM workflow provide a wealth of additional information which can be used to improve understanding of hillslope processes and aid in gully erosion management. Visual interpretation of the 3D model of the gully site for example, allows detailed description of gully morphology and erosion features in a more systematic way than can be achieved in the field (Figure 3). Similarly, the ortho-photo mosaics provide valuable insights into landscape factors which may influence gully development (e.g., ground cover type and spatial arrangement, cattle trails, roads). Ortho-photo mosaics and 3D models also provide excellent resources to visually communicate the benefits of improved land management to a range of stakeholders.

\subsubsection{Low survey instrument costs and survey time}

A major strength of SfM is the low survey instrument costs. In our study, we utilised a lightweight UAV $(<2 \mathrm{~kg})$ and camera (total cost including accessories was $\sim$ \$AUD 2000) to capture aerial imagery at the hillslope scale, and a digital single-lens reflex camera (total cost including accessories was $\sim$ \$AUD 2500) to capture ground-based imagery at the individual gully scale. The SfM instrument costs are considerably lower than airborne LiDAR and TLS, both of which cost > \$AUD 100,000 to purchase outright or, if data are provided by an external consultant, can cost between \$AUD 1000 and 2000 per $\mathrm{km}^{2}$ [106]. The low SfM survey instrument costs mean they can be purchased outright and deployed rapidly. In Australia, lightweight drones $(<2 \mathrm{~kg})$ can be used without a remote pilot license [107], representing a substantial cost saving of several thousand dollars. In our study, the UAV and Ground survey took approximately four and two hours of survey time, respectively, somewhat faster than survey times of equivalent LiDAR approaches [106]. Information generated from SfM survey therefore has the potential to enable cost-effective prioritization of gully erosion hotspots at a hillslope scale (via aerial surveys), and to be used as a tool in the design, monitoring and evaluation of gully remediation activities at individual gully scales (via ground-based survey).

\subsection{Limitations}

\subsubsection{Vegetation}

Vegetation presents a significant challenge for the generation of accurate topographic models for use in environmental modelling [108]. Vegetation is particularly problematic for SfM in tropical savannas, which are characterised by a grassy understory of variable density and structure and a discontinuous layer of trees and shrubs. Vegetation obstructs the view of the ground, is prone to movement (key-point matching algorithms rely on a static scene), and has a complex structure that is difficult to reconstruct [13,101,102]. While visual inspection of the DSMs did not reveal any distinct patterns in errors between bare and vegetated patches, it is likely that the high ground cover at the time of survey reduced the accuracy of the topographic models as highlighted in other studies $[18,26,101,103]$. For example, Cook [101] found that in sparsely vegetated areas, the SfM point cloud closely matched the ground returns of LiDAR, but struggled to accurately represent ground surface in areas of denser grass, bush, and trees. Similarly, Javernick [26] reported much higher RMSE values for vegetated surfaces $(0.78 \mathrm{~m})$ compared to bare areas $(0.17 \mathrm{~m})$. We tested several methods of vegetation classification and removal (e.g., using PhotoScan's 'classification' procedure $[98,109]$ ), resampling the point cloud at larger grid sizes where vegetation clusters are observed, and extracting 
the minimum value within the wider area [26], and point cloud classification based on multi-scale dimensionality criteria [110]). None of these methods adequately classified vegetation across our study site. Vegetation filtering from the SfM datasets was not the focus of this study, but is an active area of research [e.g., 111,112,113]. If suitable vegetation filtering methods can be developed and easily applied to SfM datasets, it will greatly enhance the ability of SfM to accurately reconstruct ground topography in densely vegetated areas.

\subsubsection{Methodological uncertainty}

While implementation of the SfM workflow is relatively straightforward, accuracy of the final topographic models depends on the methodological approach used. General guidelines for SfM surveys have been described [e.g., 18], but there remains much uncertainty as to optimal survey and processing designs for different landscapes and geomorphological conditions and applications. SfM practitioners must therefore test and adapt their methodological approach to suit their particular landscape and survey goals prior to implementing broad-scale surveys. Here we highlight two key methodological considerations, namely: the number and distribution of GCPs and the method of image capture.

The number and distribution of GCPs has a strong influence on survey time and the quality of surface reconstruction $[13,19,44,102,114]$. In our UAV dataset, despite very low georeferencing error of GCPs, much greater elevation errors were observed in the final topographic model. It is likely that the number and distribution of GCPs was insufficient to properly parameterize the 3D model during bundle adjustment (explained in [18]). While a minimum of three GCPs are required to account for model rotation, translation, and scale during the implementation of bundle adjustment algorithms, research suggests that collection of more GCPs is better and these should adequately cover the area of interest $[17,44,115,116]$. Specific GCP requirements will, however, vary depending on site characteristics, quality of the image network used in surface reconstruction, and required accuracy of the final topographic model $[19,44]$. Given the effect of GCPs on surface reconstruction quality and the considerable field effort required to collect them, determining the optimal number and distribution of GCPs remains an important research priority.

The method of image capture also has a strong bearing on survey and processing time and the quality of surface reconstruction. For example, during the Ground survey, we captured successive images approximately every meter along multiple path lines and viewing directions with slight angular changes (Figure 4c). While this approach required a large number of images and long processing times ( $\sim 110$ hours), it resulted in a model with few holes (with no data) and generally accurate surface reconstruction. Earlier attempts at image capture following a less systematic approach, significantly reduced the quality of surface reconstruction. During the UAV survey, images were captured at height of $\sim 90 \mathrm{~m}$ above the ground, with a single nadir (vertical) viewing direction, and a single orthographic grid flight path. This flight strategy was selected as it provided a good compromise between the extent of the survey area covered, and survey time. Recent studies have reported a decrease in model accuracy with increasing survey distance $[18,19]$ and also demonstrated that using vertical imagery alone can introduce systematic broad-scale error into topographic models, expressed as vertical 'doming' $[44,115,117]$. The addition of convergent (nonnadir) imagery into aerial surveys has recently been shown to improve model accuracy $[18,115]$. Further testing to determine the optimum number, overlap, height and angle of image of acquisition would enable faster and more efficient survey and processing time and help to improve model accuracy.

\subsubsection{Computational demands}

The high number and resolution of images captured during SfM surveys means that data storage, processing and analysis is computationally demanding. For example, data from the UAV and Ground survey took approximately 31 hours and 110 hours respectively to process on a computer with 8 GB graphics card, two CPU cores, and 128 GB RAM. Such computational demands may limit the scale at which SfM is currently applied and to practioners who have access to high performance 
computers. However, rapid advances in computing capability, for example through improvements to Graphics Processing Units and the implementation of parallel computing, are revolutionizing SfM workflows [19]. As high performance computers become more readily available, broader-scale implementation of both aerial and ground-based SfM approaches can be expected.

Table 5: Comparison of time and resource requirements (numbers in bracket represent normalized values per ha), and strengths and limitations of UAV vs. Ground SfM and opportunities for further research.

\begin{tabular}{|c|c|c|}
\hline & UAV SfM & Ground SfM \\
\hline Area (ha) & 71.5 & 0.065 \\
\hline $\begin{array}{l}\text { Field data capture time } \\
\text { [site surveying, image } \\
\text { capture] (hours) }\end{array}$ & $4(0.06)$ & $2(30.77)$ \\
\hline $\begin{array}{l}\text { Processing CPU time } \\
\text { [SfM, geo-referencing, MVS, } \\
\text { 3D model and ortho-photo } \\
\text { mosaic generation] (hours) }\end{array}$ & $31(0.043)$ & $110(1692.31)$ \\
\hline $\begin{array}{l}\text { Post-processing person time } \\
\text { [Data cleaning, DSM } \\
\text { generation] (hours) }\end{array}$ & $4(0.06)$ & $4(61.54)$ \\
\hline $\begin{array}{l}\text { Approximate cost of } \\
\text { hardware } \\
\text { [UAV, Camera + Lens, } \\
\text { Batteries] (\$AUD) }\end{array}$ & 2,000 & 2,500 \\
\hline $\begin{array}{l}\text { Approximate cost of software } \\
\text { (\$AUD) }\end{array}$ & 550 & 550 \\
\hline Spatial resolution $(\mathrm{m})$ & $0.1 \mathrm{~m}$ & $0.01 \mathrm{~m}$ \\
\hline Error $(\mathrm{m})$ & $\sim 0.5-1.3 \mathrm{~m}$ & $\sim 0.1 \mathrm{~m}$ \\
\hline Application & $\begin{array}{l}\text { Cost-effective high resolution }(0.1 \mathrm{~m}) \\
\text { gully and ground cover mapping at a } \\
\text { hillslope scale (e.g., 1-100 ha). }\end{array}$ & $\begin{array}{l}\text { Cost-effective very high resolution }(0.01 \mathrm{~m}) \\
\text { 3D modelling of gully morphology at an } \\
\text { individual gully scale (e.g., } 0.01-0.2 \mathrm{ha} \text { ). }\end{array}$ \\
\hline Strengths & $\begin{array}{l}\text { Provides high resolution DSMs at a } \\
\text { hillslope scale, with elevation error } \\
\text { comparable to airborne LiDAR. } \\
\text { - Provides high resolution ortho-photo } \\
\text { mosaics which can be used to assess } \\
\text { ground cover (e.g. ground cover } \\
\text { spatial arrangement, cattle trails, } \\
\text { roads) and is valuable for land } \\
\text { management communication. } \\
\text { Instrument costs and survey time are } \\
\text { low compared to airborne LiDAR. }\end{array}$ & $\begin{array}{l}\text { - Provides very high resolution DSMs at } \\
\text { an individual gully scale, with elevation } \\
\text { error comparable to TLS. } \\
\text { - Provides very high resolution 3D models } \\
\text { which can be used to assess gully } \\
\text { morphology and describe key erosion } \\
\text { features. } \\
\text { - Instrument costs and survey time are } \\
\text { low compared to TLS. }\end{array}$ \\
\hline Limitations & \multicolumn{2}{|c|}{$\begin{array}{l}\text { - The complex structure, pattern and movement of vegetation in tropical savanna } \\
\text { negatively affects model accuracy. } \\
\text { - The accuracy of the final topographic models strongly depends on the } \\
\text { methodological approach implemented. There remains much uncertainty as to } \\
\text { optimal survey and processing designs for different landscapes and } \\
\text { geomorphological applications. } \\
\text { - The high number of images captured, mean that data storage, processing and } \\
\text { analysis is computationally demanding. }\end{array}$} \\
\hline Opportunities & \multicolumn{2}{|c|}{$\begin{array}{l}\text { Further research is needed to: } \\
\text { - Determine SfM survey repeatability and it's the ability to detect geomorphic change. } \\
\text { - Develop effective and easily applied methods of vegetation filtering from SfM } \\
\text { datasets. } \\
\text { - Determine the optimal number and distribution of GCPs across the landscape. } \\
\text { - Determine the optimum number, overlap, height and angle of image of acquisition. }\end{array}$} \\
\hline
\end{tabular}

\subsection{Conclusion}

Structure from Motion with Multi-View Stereo photogrammetry (SfM) is increasingly utilised as a cost-effective method of rapidly acquiring high resolution topographic data across a range of scales and in diverse landscapes and geomorphic settings, but has not been thoroughly tested in gullied 
tropical savanna systems. The aim of this study was to test the accuracy of topographic models derived from aerial (via an Unmanned Aerial Vehicle, 'UAV') and ground-based (via a handheld digital camera, 'Ground') SfM in modelling a hillslope gully system in grazed dry-tropical savanna, and to assess the strengths and limitations of the approach applied at different scales. Our results indicate UAV SfM can deliver topographic models with a resolution and accuracy suitable to define gully systems at a hillslope scale (e.g., $0.1 \mathrm{~m}$ resolution with $\sim 0.5-1.3 \mathrm{~m}$ elevation error), while ground-based SfM is more capable of quantifying gully morphology (e.g., $0.01 \mathrm{~m}$ resolution with $0.1 \mathrm{~m}$ elevation error). High resolution 3D topographic models and ortho-photo mosaics, produced as part of the SfM workflow, allow detailed description of gully morphology and contributing area characteristics (e.g., ground cover type and spatial arrangement), providing valuable information for land management. Very low survey instrument costs $(<\$ A U D 3,000)$ and rapid survey time $(4$ and 2 hours for UAV and Ground survey respectively) mean that SfM is highly cost-effective, compared to equivalent Light Detection and Ranging (LiDAR) techniques. While SfM offers great potential, this study has also identified some important limitations of the methodology. For example, accurately reconstructing ground topography in densely vegetated areas, common across tropical savanna landscapes, remains a major challenge for SfM workflows, and requires the development of improved vegetation filtering methods. The accuracy of the final topographic models also depends on the methodological approach used, and there remains uncertainty as to optimal survey and processing designs. Further testing and refinement of different methodological approaches would help to improve model accuracy and reduce processing times, and would be of great value to nonexpert SfM practitioners. Finally, high computational demands for image processing may limit the spatial scale at which SfM is currently implemented, and the number of practioners who can apply it. However, as high performance computing becomes more readily available, broader-scale application of SfM can be expected. Overall, this study has demonstrated great potential for SfM to be used as a cost-effective tool to aid in the mapping, modelling, and management of complex hillslope gully systems at different scales, in tropical savanna landscapes and elsewhere. 
Supplementary material: The following are available online at www.mdpi.com/link

Table S1: PhotoScan processing parameters and times for UAV and Ground survey datasets.

Table S1. PhotoScan processing parameters and times for UAV and Ground survey datasets

\begin{tabular}{lcc}
\hline & UAV & Ground \\
\hline Structure from motion & & \\
Number of cameras (images) & 938 & 1747 \\
Number of aligned cameras & 938 & 1702 \\
Alignment parameters & & \\
Accuracy & High & High \\
Pair preselection & Generic & Generic \\
Key point limit & 40,000 & 40,000 \\
Tie point limit & 4,000 & 4,000 \\
Constrain features by mask & No & No \\
Adaptive camera model fitting & Yes & Yes \\
Sparse point cloud number of points & 468,222 & $1,320,348$ \\
RMS reprojection error & $0.302(0.997$ pix) & $0.106(0.535$ pix $)$ \\
Max reprojection error & $1.251(54.852$ pix $)$ & $0.671(27.301$ pix) \\
Matching time (hr) & 2.08 & 7.0 \\
Alignment time (hr) & 1.95 & 0.63 \\
\hline Scaling, Georeferencing, Optimization & & \\
Number of Ground Control Points & 7 & 10 \\
Camera accuracy (m) & 10 & 10 \\
Camera accuracy (deg) & 2 & 2 \\
Marker accuracy (m) & 0.002 & 0.002 \\
Marker accuracy (pix) & 0.1 & 0.1 \\
Tie point accuracy (pix) & 1 & 1 \\
Optimization parameters & $\mathrm{p} 1, \mathrm{p} 2$ & $\mathrm{p} 1, \mathrm{p} 2$ \\
& 0.05 & 0.11 \\
Optimization time (hr) & &
\end{tabular}

\section{Multi-View Stereo}

Reconstruction parameters

Quality

Depth filtering

Dense point cloud number of points

Depth maps generation time (hr)

Dense cloud generation time (hr)

Textured 3D model, and Ortho-photo mosaic

Mesh generation processing time

Texturing processing time

High

Aggressive

$189,299,097$

9.67

2.28

0.68

4.06

10.0

High

Aggressive

$112,896,341$

$19.18(3.2)^{*}$

$471.0(78.5)^{*}$

Ortho-photo mosaic generation processing time

Total processing time (hr)

31

$5.30(2.65)^{*}$

$7.10(3.55)^{*}$

$28.0(14)^{*}$

*Values in brackets indicate estimated true processing time. As multiple gully systems were analysed simultaneously, processing times (reported by PhotoScan) for individual gully systems are significantly higher than what would be expected if gullies were processed individually.

Acknowledgments: This project was supported by: the Australian Government Australian Postgraduate Awards (APA) program; a Meat and Livestock Australia (MLA) Postgraduate Award; and a Commonwealth Scientific and Industrial Research Organisation (CSIRO) Postgraduate Scholarship. Funds from these sources were used to cover the costs of publishing in open access. The LiDAR DEM of Weany Creek was provided by Dan Tindall (Queensland Department of Science, Information Technology and Innovation). Anne Henderson (CSIRO) aided in the preparation of Figure 1. We gratefully acknowledge Rob and Sue Benetto of Virginia Park 
Station for allowing access onto their property to undertake this work, and two anonymous reviewers who provided comments and review on early versions of this manuscript.

Author Contributions: Jack Koci conceived and designed the study; collected and analyzed the data, and wrote the manuscript. Javier Leon, Ben Jarihani and Roy Sidle provided input into the design of the study, aided in data collection and in the interpretation of the results, and provided input into the writing of the manuscript. Scott Wilkinson and Rebecca Bartley aided in the design of the study, assisted in the interpretation of the results, and provided input into the writing of the manuscript.

Conflicts of Interest: The authors declare no conflict of interest. The funding sponsors had no role in the design of the study; in the collection, analyses, or interpretation of data; in the writing of the manuscript, and in the decision to publish the results.

\section{References}

1. Poesen, J.; Nachtergaele, J.; Verstraeten, G.; Valentin, C. Gully erosion and environmental change: Importance and research needs. CATENA 2003, 50, 91-133, http://dx.doi.org/10.1016/S0341-8162(02)00143$\underline{1 .}$

2. Valentin, C.; Poesen, J.; Li, Y. Gully erosion: Impacts, factors and control. CATENA 2005, 63, 132-153, http://dx.doi.org/10.1016/j.catena.2005.06.001.

3. Castillo, C.; Gómez, J.A. A century of gully erosion research: Urgency, complexity and study approaches. Earth-Sci. Rev. 2016, 160, 300-319, https://doi.org/10.1016/j.earscirev.2016.07.009.

4. Poesen, J.; Vanwalleghem, T.; de Vente, J.; Knapen, A.; Verstraeten, G.; Martínez-Casasnovas, J.A. Gully erosion in europe. In Soil erosion in europe, Wiley: West Sussex, England, 2006; pp 515-536.

5. Olley, J.M.; Wasson, R.J. Changes in the flux of sediment in the upper murrumbidgee catchment, southeastern australia, since european settlement. Hydrol. Process. 2003, 17, 3307-3320, DOI: 10.1002/hyp.1388.

6. Wilson, G.V.; Cullum, R.F.; Römkens, M.J.M. Ephemeral gully erosion by preferential flow through a discontinuous soil-pipe. CATENA 2008, 73, 98-106, http://dx.doi.org/10.1016/j.catena.2007.09.008.

7. Zhao, J.; Vanmaercke, M.; Chen, L.; Govers, G. Vegetation cover and topography rather than human disturbance control gully density and sediment production on the chinese loess plateau. Geomorphology 2016, 274, 92-105, https://doi.org/10.1016/j.geomorph.2016.09.022.

8. Betts, H.D.; Trustrum, N.A.; Rose, R.C.D. Geomorphic changes in a complex gully system measured from sequential digital elevation models, and implications for management. Earth Surf. Process. Landf. 2003, 28, 1043-1058, https://doi.org/10.1002/esp.500.

9. Lal, R. Restoring land degraded by gully erosion in the tropics. In Advances in soil science. Volume 17. Soil restoration, Lal, R.; Stewart, B.A.; Cronk, J.K., Eds. Springer-Verlag: New York; Berlin, 1992; Vol. 17, pp 123-152.

10. Vanmaercke, M.; Poesen, J.; Van Mele, B.; Demuzere, M.; Bruynseels, A.; Golosov, V.; Bezerra, J.F.R.; Bolysov, S.; Dvinskih, A.; Frankl, A., et al. How fast do gully headcuts retreat? Earth-Sci. Rev. 2016, 154, 336-355, http://dx.doi.org/10.1016/j.earscirev.2016.01.009.

11. Liu, X. Airborne lidar for dem generation: Some critical issues. Prog. in Phys. Geogr. 2008, 32, 31-49, DOI: $10.1177 / 0309133308089496$.

12. Telling, J.; Lyda, A.; Hartzell, P.; Glennie, C. Review of earth science research using terrestrial laser scanning. Earth-Sci. Rev. 2017, 169, 35-68, https://doi.org/10.1016/j.earscirev.2017.04.007.

13. Smith, M.W.; Carrivick, J.L.; Quincey, D.J. Structure from motion photogrammetry in physical geography. Prog. in Phys. Geogr. 2015, 1-29, DOI: 10.1177/0309133315615805. 
14. Perroy, R.L.; Bookhagen, B.; Asner, G.P.; Chadwick, O.A. Comparison of gully erosion estimates using airborne and ground-based lidar on santa cruz island, california. Geomorphology 2010, 118, 288-300, DOI: 10.1016/j.geomorph.2010.01.009.

15. Goodwin, N.R.; Armston, J.; Stiller, I.; Muir, J. Assessing the repeatability of terrestrial laser scanning for monitoring gully topography: A case study from aratula, queensland, australia. Geomorphology 2016, 2436, http://dx.doi.org/10.1016/j.geomorph.2016.03.007.

16. Westoby, M.J.; Brasington, J.; Glasser, N.F.; Hambrey, M.J.; Reynolds, J.M. 'Structure-from-motion' photogrammetry: A low-cost, effective tool for geoscience applications. Geomorphology 2012, 179, 300-314, http://dx.doi.org/10.1016/j.geomorph.2012.08.021.

17. James, M.R.; Robson, S. Straightforward reconstruction of $3 \mathrm{~d}$ surfaces and topography with a camera: Accuracy and geoscience application. J. Geophys. Res. Earth Surf. 2012, 117, F03017, DOI: 10.1029/2011JF002289.

18. Smith, M.W.; Vericat, D. From experimental plots to experimental landscapes: Topography, erosion and deposition in sub-humid badlands from structure-from-motion photogrammetry. Earth Surf. Process. Landf. 2015, 40, 1656-1671, DOI: 10.1002/esp.3747.

19. Eltner, A.; Kaiser, A.; Castillo, C.; Rock, G.; Neugirg, F.; Abellán, A. Image-based surface reconstruction in geomorphometry - merits, limits and developments. Earth Surf. Dynam. 2016, 4, 359-389, DOI: 10.5194/esurf-4-359-2016.

20. Piermattei, L.; Carturan, L.; Guarnieri, A. Use of terrestrial photogrammetry based on structure-frommotion for mass balance estimation of a small glacier in the italian alps. Earth Surf. Process. Landf. 2015, 40, 1791-1802, DOI: 10.1002/esp.3756.

21. Gómez-Gutiérrez, Á.; de Sanjosé-Blasco, J.; de Matías-Bejarano, J.; Berenguer-Sempere, F. Comparing two photo-reconstruction methods to produce high density point clouds and dems in the corral del veleta rock glacier (sierra nevada, spain). Rem. Sens. 2014, 6, 5407-5427, DOI: 10.3390/rs6065407.

22. Stumpf, A.; Malet, J.P.; Allemand, P.; Pierrot-Deseilligny, M.; Skupinski, G. Ground-based multi-view photogrammetry for the monitoring of landslide deformation and erosion. Geomorphology 2015, 231, 130145, http://dx.doi.org/10.1016/j.geomorph.2014.10.039.

23. Lucieer, A.; de Jong, S.; Turner, D. Mapping landslide displacements using structure from motion (sfm) and image correlation of multi-temporal uav photography. Prog. in Phys. Geogr. 2013, 97-116, DOI: $10.1177 / 0309133313515293$.

24. James, M.R.; Varley, N. Identification of structural controls in an active lava dome with high resolution dems: Volcán de colima, mexico. Geophys. Res. Lett. 2012, 39, L22303, DOI: 10.1029/2012GL054245.

25. Bemis, S.P.; Micklethwaite, S.; Turner, D.; James, M.R.; Akciz, S.; Thiele, S.T.; Bangash, H.A. Ground-based and uav-based photogrammetry: A multi-scale, high-resolution mapping tool for structural geology and paleoseismology. J Struct Geol 2014, 69, Part A, 163-178, http://dx.doi.org/10.1016/j.jsg.2014.10.007.

26. Javernick, L.; Brasington, J.; Caruso, B. Modeling the topography of shallow braided rivers using structurefrom-motion photogrammetry. Geomorphology 2014, 213, 166-182, http://dx.doi.org/10.1016/j.geomorph.2014.01.006.

27. Dietrich, J.T. Riverscape mapping with helicopter-based structure-from-motion photogrammetry. Geomorphology 2016, 252, 144-157, http://dx.doi.org/10.1016/j.geomorph.2015.05.008.

28. Woodget, A.S.; Carbonneau, P.E.; Visser, F.; Maddock, I.P. Quantifying submerged fluvial topography using hyperspatial resolution uas imagery and structure from motion photogrammetry. Earth Surf. Process. Landf. 2015, 40, 47-64, DOI: 10.1002/esp.3613. 
29. Smith, M.W.; Carrivick, J.L.; Hooke, J.; Kirkby, M.J. Reconstructing flash flood magnitudes using 'structure-from-motion': A rapid assessment tool. J Hydrol 2014, 519, Part B, 1914-1927, http://dx.doi.org/10.1016/j.jhydrol.2014.09.078.

30. Mancini, F.; Dubbini, M.; Gattelli, M.; Stecchi, F.; Fabbri, S.; Gabbianelli, G. Using unmanned aerial vehicles (uav) for high-resolution reconstruction of topography: The structure from motion approach on coastal environments. Rem. Sens. 2013, 5, 6880, DOI: 10.3390/rs5126880.

31. Bryson, M.; Johnson-Roberson, M.; Murphy, R.J.; Bongiorno, D. Kite aerial photography for low-cost, ultra-high spatial resolution multi-spectral mapping of intertidal landscapes. PLoS ONE 2013, 8, e73550, DOI: 10.1371/journal.pone.0073550.

32. Figueira, W.; Ferrari, R.; Weatherby, E.; Porter, A.; Hawes, S.; Byrne, M. Accuracy and precision of habitat structural complexity metrics derived from underwater photogrammetry. Rem. Sens. 2015, 7, 15859, DOI: $10.3390 / \mathrm{rs} 71215859$.

33. Leon, J.X.; Roelfsema, C.M.; Saunders, M.I.; Phinn, S.R. Measuring coral reef terrain roughness using 'structure-from-motion' close-range photogrammetry. Geomorphology 2015, 242, 21-28, http://dx.doi.org/10.1016/j.geomorph.2015.01.030.

34. Brunier, G.; Fleury, J.; Anthony, E.J.; Gardel, A.; Dussouillez, P. Close-range airborne structure-frommotion photogrammetry for high-resolution beach morphometric surveys: Examples from an embayed rotating beach. Geomorphology 2016, 261, 76-88, http://dx.doi.org/10.1016/j.geomorph.2016.02.025.

35. Nouwakpo, S.K.; Weltz, M.A.; McGwire, K. Assessing the performance of structure-from-motion photogrammetry and terrestrial lidar for reconstructing soil surface microtopography of naturally vegetated plots. Earth Surf. Process. Landf. 2016, 41, 308-322, DOI: 10.1002/esp.3787.

36. Ouédraogo, M.M.; Degré, A.; Debouche, C.; Lisein, J. The evaluation of unmanned aerial system-based photogrammetry and terrestrial laser scanning to generate dems of agricultural watersheds. Geomorphology 2014, 214, 339-355, http://dx.doi.org/10.1016/j.geomorph.2014.02.016.

37. Nouwakpo, S.K.; James, M.R.; Weltz, M.A.; Huang, C.H.; Chagas, I.; Lima, L. Evaluation of structure from motion for soil microtopography measurement. Photogramm. Rec. 2014, 29, 297-316, DOI: 10.1111/phor.12072.

38. Castillo, C.; James, M.; Redel-Macías, M.; Pérez, R.; Gómez, J. Sf3m software: 3-d photo-reconstruction for non-expert users and its application to a gully network. Soil 2015, 1, 583-594, DOI: 10.5194/soil-1-583-2015.

39. Castillo, C.; Taguas, E.V.; Zarco-Tejada, P.; James, M.R.; Gómez, J.A. The normalized topographic method: An automated procedure for gully mapping using gis. Earth Surf. Process. Landf. 2014, 39, 2002-2015, DOI: 10.1002/esp.3595.

40. Gómez-Gutiérrez, Á.; Schnabel, S.; Berenguer-Sempere, F.; Lavado-Contador, F.; Rubio-Delgado, J. Using 3d photo-reconstruction methods to estimate gully headcut erosion. CATENA 2014, 120, 91-101, http://dx.doi.org/10.1016/j.catena.2014.04.004.

41. Stöcker, C.; Eltner, A.; Karrasch, P. Measuring gullies by synergetic application of uav and close range photogrammetry - a case study from andalusia, spain. CATENA 2015, 132, 1-11, https://doi.org/10.1016/j.catena.2015.04.004.

42. Di Stefano, C.; Ferro, V.; Palmeri, V.; Pampalone, V.; Agnello, F. Testing the use of an image-based technique to measure gully erosion at sparacia experimental area. Hydrol. Process. 2017, 31, 573-585, DOI: 10.1002/hyp.11048.

43. d'Oleire-Oltmanns, S.; Marzolff, I.; Peter, K.; Ries, J. Unmanned aerial vehicle (uav) for monitoring soil erosion in morocco. Rem. Sens. 2012, 4, 3390, DOI: 10.3390/rs4113390. 
44. James, M.R.; Robson, S.; d'Oleire-Oltmanns, S.; Niethammer, U. Optimising uav topographic surveys processed with structure-from-motion: Ground control quality, quantity and bundle adjustment. Geomorphology 2017, 280, 51-66, http://dx.doi.org/10.1016/j.geomorph.2016.11.021.

45. Peter, K.D.; d'Oleire-Oltmanns, S.; Ries, J.B.; Marzolff, I.; Ait Hssaine, A. Soil erosion in gully catchments affected by land-levelling measures in the souss basin, morocco, analysed by rainfall simulation and uav remote sensing data. CATENA 2014, 113, 24-40, https://doi.org/10.1016/j.catena.2013.09.004.

46. Frankl, A.; Stal, C.; Abraha, A.; Nyssen, J.; Rieke-Zapp, D.; De Wulf, A.; Poesen, J. Detailed recording of gully morphology in $3 \mathrm{~d}$ through image-based modelling. CATENA 2015, 127, 92-101, http://dx.doi.org/10.1016/j.catena.2014.12.016.

47. Glendell, M.; McShane, G.; Farrow, L.; James, M.R.; Quinton, J.; Anderson, K.; Evans, M.; Benaud, P.; Rawlins, B.; Morgan, D., et al. Testing the utility of structure-from-motion photogrammetry reconstructions using small unmanned aerial vehicles and ground photography to estimate the extent of upland soil erosion. Earth Surf. Process. Landf. 2017, n/a-n/a, DOI: 10.1002/esp.4142.

48. Christian, P.; Davis, J. Hillslope gully photogeomorphology using structure-from-motion. Zeitschrift für Geomorphologie, Supplementary Issues 2016, 60, 59-78, DOI: 10.1127/zfg_suppl/2016/00238.

49. Gesch, K.R.; Wells, R.R.; Cruse, R.M.; Momm, H.G.; Dabney, S.M. Quantifying uncertainty of measuring gully morphological evolution with close-range digital photogrammetry. Soil Sci. Soc. Am. J. 2015, 79, 650659, DOI: 10.2136/sssaj2014.10.0396.

50. Wells, R.R.; Momm, H.G.; Castillo, C. Quantifying uncertainty in high-resolution remotely sensed topographic surveys for ephemeral gully channel monitoring. Earth Surf. Dynam. 2017, 5, 347-367, DOI: 10.5194/esurf-5-347-2017.

51. Lannoeye, W.; Stal, C.; Guyassa, E.; Zenebe, A.; Nyssen, J.; Frankl, A. The use of sfm-photogrammetry to quantify and understand gully degradation at the temporal scale of rainfall events: An example from the ethiopian drylands. Phys. Geogr. 2016, 37, 430-451, DOI: 10.1080/02723646.2016.1234197.

52. Liu, K.; Ding, H.; Tang, G.; Na, J.; Huang, X.; Xue, Z.; Yang, X.; Li, F. Detection of catchment-scale gullyaffected areas using unmanned aerial vehicle (uav) on the chinese loess plateau. ISPRS int. j. geo-inf. 2016, 5, 238, DOI: 10.3390/ijgi5120238.

53. Wang, R.; Zhang, S.; Pu, L.; Yang, J.; Yang, C.; Chen, J.; Guan, C.; Wang, Q.; Chen, D.; Fu, B., et al. Gully erosion mapping and monitoring at multiple scales based on multi-source remote sensing data of the sancha river catchment, northeast china. ISPRS int. j. geo-inf. 2016, 5, 200, DOI: 10.3390/ijgi5110200.

54. Zhang, B.; Xiong, D.; Su, Z.; Yang, D.; Dong, Y.; Xiao, L.; Zhang, S.; Shi, L. Effects of initial step height on the headcut erosion of bank gullies: A case study using a $3 \mathrm{~d}$ photo-reconstruction method in the dry-hot valley region of southwest china. Phys. Geogr. 2016, 37, 409-429, DOI: 10.1080/02723646.2016.1219939.

55. Meadows, M.E.; Thomas, D.S.G. Tropical savannas. In Geomorphology and global environmental change, Slaymaker, O.; Spencer, T.; Embleton-Hamann, C., Eds. Cambridge University Press: Cambridge, England, 2009; pp 248-275.

56. Brooks, A.; Spencer, J.; Knight, J. Alluvial gully erosion: An example from the mitchell fluvial megafan, queensland, australia. Earth Surf. Process. Landf. 2009, 34, 43-48, DOI: 10.1002/esp.1883.

57. Bartley, R.; Hawdon, A.; Post, D.A.; Roth, C.H. A sediment budget for a grazed semi-arid catchment in the burdekin basin, australia. Geomorphology 2007, 87, 302-321, http://dx.doi.org/10.1016/j.geomorph.2006.10.001. 
58. Bartley, R.; Bainbridge, Z.T.; Lewis, S.E.; Kroon, F.J.; Wilkinson, S.N.; Brodie, J.E.; Silburn, D.M. Relating sediment impacts on coral reefs to watershed sources, processes and management: A review. Sci. Total Environ. 2014, 468-469, 1138-1153, http://dx.doi.org/10.1016/j.scitotenv.2013.09.030.

59. Brodie, J.; Waterhouse, J.; Schaffelke, B.; Kroon, F.; Thorburn, P.; Rolfe, J.; Johnson, J.; Fabricius, K.; Lewis, S.; Devlin, M., et al. 2013 scientific consensus statement: Land use impacts on great barrier reef water quality and ecosystem condition; The State of Queensland: Brisbane, Australia, 2013.

60. Kroon, F.J.; Thorburn, P.; Schaffelke, B.; Whitten, S. Towards protecting the great barrier reef from landbased pollution. Global Change Biol. 2016, 22, 1985-2002, DOI: 10.1111/gcb.13262.

61. Thorburn, P.J.; Wilkinson, S.N. Conceptual frameworks for estimating the water quality benefits of improved agricultural management practices in large catchments. Agric., Ecosyst. Environ. 2013, 180, 192209, http://dx.doi.org/10.1016/j.agee.2011.12.021.

62. Waters, D.; Carroll, C.; Ellis, R.; Hateley, L.; McCloskey, G.; Packett, R.; Dougall, C.; Fentie. Modelling reductions of pollutant loads due to improved management practices in the great barrier reef catchments - whole of gbr; Queensland Department of Natural Resources and Mines: Toowoomba, Australia, 2014.

63. Caitcheon, G.G.; Olley, J.M.; Pantus, F.; Hancock, G.; Leslie, C. The dominant erosion processes supplying fine sediment to three major rivers in tropical australia, the daly (nt), mitchell (qld) and flinders (qld) rivers. Geomorphology 2012, 151-152, 188-195, http://dx.doi.org/10.1016/j.geomorph.2012.02.001.

64. Hughes, A.O.; Olley, J.M.; Croke, J.C.; McKergow, L.A. Sediment source changes over the last 250 years in a dry-tropical catchment, central queensland, australia. Geomorphology 2009, 104, 262-275, http://dx.doi.org/10.1016/j.geomorph.2008.09.003.

65. Tims, S.G.; Everett, S.E.; Fifield, L.K.; Hancock, G.J.; Bartley, R. Plutonium as a tracer of soil and sediment movement in the herbert river, australia. Nucl Instrum Methods Phys Res B 2010, 268, 1150-1154, http://dx.doi.org/10.1016/j.nimb.2009.10.121.

66. Wasson, R.J.; Furlonger, L.; Parry, D.; Pietsch, T.; Valentine, E.; Williams, D. Sediment sources and channel dynamics, daly river, northern australia. Geomorphology 2010, 114, 161-174, http://dx.doi.org/10.1016/j.geomorph.2009.06.022.

67. Olley, J.; Brooks, A.; Spencer, J.; Pietsch, T.; Borombovits, D. Subsoil erosion dominates the supply of fine sediment to rivers draining into princess charlotte bay, australia. J. Environ. Radioact. 2013, 124, 121-129, http://dx.doi.org/10.1016/j.jenvrad.2013.04.010.

68. Furuichi, T.; Olley, J.; Wilkinson, S.; Lewis, S.; Bainbridge, Z.; Burton, J. Paired geochemical tracing and load monitoring analysis for identifying sediment sources in a large catchment draining into the great barrier reef lagoon. Geomorphology 2016, 266, 41-52, http://dx.doi.org/10.1016/j.geomorph.2016.05.008.

69. Fabricius, K.E. Effects of terrestrial runoff on the ecology of corals and coral reefs: Review and synthesis. Mar. Pollut. Bull. 2005, 50, 125-146, https://doi.org/10.1016/j.marpolbul.2004.11.028.

70. Brodie, J.E.; Lewis, S.E.; Collier, C.J.; Wooldridge, S.; Bainbridge, Z.T.; Waterhouse, J.; Rasheed, M.A.; Honchin, C.; Holmes, G.; Fabricius, K. Setting ecologically relevant targets for river pollutant loads to meet marine water quality requirements for the great barrier reef, australia: A preliminary methodology and analysis. Ocean Coast. Manage. 2016, http://dx.doi.org/10.1016/j.ocecoaman.2016.09.028.

71. Wilkinson, S.N.; Bartley, R.; Hairsine, P.B.; Bui E.N; Gregory L; A.E, H. Managing gully erosion as an efficient approach to improving water quality in the great barrier reef lagoon. Report to the department of the environment; CSIRO Land and Water: Canberra, Australia, 2015.

72. Hughes, A.; Prosser, P.; Stevenson, J.; Scott, A.; Lu, H.; Gallant, J.; Moran, C. Gully erosion mapping for the national land and water audit; Technical Report 26/01; CSIRO Land and Water: Canberra, Australia, 2001. 
73. Kuhnert, P.; Kinsey-Henderson, A.; Bartley, R.; Herr, A. Incorporating uncertainty in gully erosion calculations using the random forests modelling approach. Environmetrics 2010, 21, 493-509, DOI: 10.1002/env.999.

74. Prosser, I.P.; Rustomji, P.; Young, W.J.; Moran, C.J.; Hughes, A.O. Constructing river basin sediment budgets for the national land and water resources audit. Csiro land and water, technical report 15/01; CSIRO: Canberra, Australia, 2001.

75. Wilkinson, S.N.; Prosser, I.P.; Rustomji, P.; Read, A.M. Modelling and testing spatially distributed sediment budgets to relate erosion processes to sediment yields. Environ. Model. Software 2009, 24, 489-501, http://dx.doi.org/10.1016/j.envsoft.2008.09.006.

76. Wilkinson, S.N.; Dougall, C.; Kinsey-Henderson, A.E.; Searle, R.; Ellis, R.; Bartley, R. Development of a time-stepping sediment budget model for assessing land use impacts in large river basins. Sci. Total Environ. 2014, 468-469, 1210-1224, DOI: 10.1016/j.scitotenv.2013.07.049.

77. McKergow, L.A.; Prosser, I.P.; Hughes, A.O.; Brodie, J. Sources of sediment to the great barrier reef world heritage area. Mar. Pollut. Bull. 2005, 51, 200-211, DOI: 10.1016/j.marpolbul.2004.11.029.

78. Waters, D.; Carroll, C.; Ellis, R.; McCloskey, G.; Hateley, L.; Packett, R.; Dougasll, C.; Fentie, B. Catchment modelling scenarios to inform gbr water quality targets. In 20th International Congress on Modelling and Simulation, Piantadosi, J.; Anderssen, R.S.; Boland, J., Eds. Adelaide, Australia, 2013.

79. Tindall, D.; Marchand, B.; Gilad, U.; Goodwin, N.; Denham, R.; Byer, S. Gully mapping and drivers in the grazing lands of the burdekin catchment. Rp66g synthesis report; The State of Queensland (Department of Science, Information Technology, Innovation and the Arts): Brisbane, Australia, 2014.

80. Goodwin, N.R.; Armston, J.D.; Muir, J.; Stiller, I. Monitoring gully change: A comparison of airborne and terrestrial laser scanning using a case study from aratula, queensland. Geomorphology 2017, 282, 195-208, https://doi.org/10.1016/j.geomorph.2017.01.001.

81. Shellberg, J.G.; Brooks, A.P.; Spencer, J.; Ward, D. The hydrogeomorphic influences on alluvial gully erosion along the mitchell river fluvial megafan. Hydrol. Process. 2013, 27, 1086-1104, DOI: 10.1002/hyp.9240.

82. Hancock, G.R.; Evans, K.G. Gully position, characteristics and geomorphic thresholds in an undisturbed catchment in northern australia. Hydrol. Process. 2006, 20, 2935-2951, DOI: 10.1002/hyp.6085.

83. Bartley, R.; Croke, J.; Bainbridge, Z.T.; Austin, J.M.; Kuhnert, P.M. Combining contemporary and longterm erosion rates to target erosion hot-spots in the great barrier reef, australia. Anthropocene 2015, 10, 112, http://dx.doi.org/10.1016/j.ancene.2015.08.002.

84. Isbell, R.F. The australian soil classification. Rev. ed. ed.; CSIRO Publishing: Collingwood, Australia, 1996.

85. Bartley, R.; Corfield, J.P.; Abbott, B.N.; Hawdon, A.A.; Wilkinson, S.N.; Nelson, B. Impacts of improved grazing land management on sediment yields, part 1: Hillslope processes. J Hydrol 2010, 389, 237-248, http://dx.doi.org/10.1016/j.jhydrol.2010.05.002.

86. Gilad, U.; Denham, R.; Tindall, D. Gullies, google earth and the great barrier reef: A remote sensing methodology for mapping gullies over extensive areas. In International Archives of the Photogrammetry, Remote Sensing and Spatial Information Science, Volume XXXIX-B8, XXII ISPRS Congress: Melbourne, Australia, 2012; pp 469-473.

87. Wilkinson, S.N.; Kinsey-Henderson, A.E.; Hawdon, A.A.; Ellis, T.W.; Nicholas, D.M. Gully erosion and its response to grazing practices in the upper burdekin catchment. A report to nq dry tropics for the paddock to reef program; CSIRO Water for a Healthy Country Flagship: Canberra, Australia, 2013. 
88. Petheram, C.; McMahon, T.A.; Peel, M.C. Flow characteristics of rivers in northern australia: Implications for development. J Hydrol 2008, 357, 93-111, DOI: 10.1016/j.jhydrol.2008.05.008.

89. Nicholls, N. The el niño/ southern oscillation and australian vegetation. Vegetatio 1991, 91, 23-36, http://www.jstor.org/stable/20038710.

90. Jarihani, B.; Sidle, R.C.; Bartley, R.; Roth, C.H.; Wilkinson, S.N. Characterisation of hydrological response to rainfall at multi spatio-temporal scales in savannas of semi-arid australia (under review). Preprints, DOI: 10.20944/preprints201706.0056.v1.

91. Mott, J.J.; Williams, J.; Andrew, M.H.; Gillison, A.N. Chapter 7: Australian savanna ecosystems. In Ecology and management of the world's savannas, Tothill, J.C.; J.J, M., Eds. Australian Academy of Sciences: Canberra, Australia, 1985; pp 56-82.

92. Williams, R.J.; Cook, G.D.; Gill, A.M.; Moore, P.H.R. Fire regime, fire intensity and tree survival in a tropical savanna in northern australia. Aust. J. Ecol. 1999, 24, 50-59, DOI: 10.1046/j.1442-9993.1999.00946.x.

93. Williams, R.; Gill, A.; Moore, P. Seasonal changes in fire behaviour in a tropical savanna in northern australia. Int. J. Wildland Fire 1998, 8, 227-239, http://dx.doi.org/10.1071/WF9980227.

94. Townsend, S.A.; Douglas, M.M. The effect of three fire regimes on stream water quality, water yield and export coefficients in a tropical savanna (northern australia). J Hydrol 2000, 229, 118-137, http://dx.doi.org/10.1016/S0022-1694(00)00165-7.

95. Wilkinson, S.N.; Kinsey-Henderson, A.E.; Hawdon, A.A.; Hairsine, P.B.; Bartley, R.; Baker, B. Gully erosion processes, dynamics and controls in a tropical savannah (under review). Earth Surf. Process. Landf.

96. Sibson, R. A brief description of natural neighbor interpolation. In Interpolating multivariate data, Barnett, V., Ed. John Wiley \& Sons: West Sussex, England, 1981; pp 21-36.

97. DJI. Phantom 3 professional user manual v1.8; 2016.

98. $\quad$ AgiSoft LLC. Agisoft photoscan professional v1.3 user manual; 2017.

99. Lowe, D.G. Distinctive image features from scale-invariant keypoints. Int J Comput Vis. 2004, 60, 91-110, DOI: 10.1023/b:visi.0000029664.99615.94.

100. Girardeau-Montaut, D. Cloudcompare: 3d point cloud and mesh processing software, v2.8; 2017.

101. Cook, K.L. An evaluation of the effectiveness of low-cost uavs and structure from motion for geomorphic change detection. Geomorphology 2017, 278, 195-208, https://doi.org/10.1016/j.geomorph.2016.11.009.

102. Carrivick, J.L.; Smith, M.W.; Quincey, D.J. Quality assessment. In Structure from motion in the geosciences, Carrivick, J.L.; Smith, M.W.; Quincey, D.J., Eds. John Wiley \& Sons, Ltd: West Sussex, England, 2016; pp 97-123.

103. Tonkin, T.N.; Midgley, N.G.; Graham, D.J.; Labadz, J.C. The potential of small unmanned aircraft systems and structure-from-motion for topographic surveys: A test of emerging integrated approaches at cwm idwal, north wales. Geomorphology 2014, 226, 35-43, https://doi.org/10.1016/j.geomorph.2014.07.021.

104. Kaiser, A.; Neugirg, F.; Rock, G.; Müller, C.; Haas, F.; Ries, J.; Schmidt, J. Small-scale surface reconstruction and volume calculation of soil erosion in complex moroccan gully morphology using structure from motion. Rem. Sens. 2014, 6, 7050-7080, DOI: 10.3390/rs6087050.

105. Castillo, C.; Pérez, R.; James, M.R.; Quinton, J.N.; Taguas, E.V.; Gómez, J.A. Comparing the accuracy of several field methods for measuring gully erosion. Soil Sci. Soc. Am. J. 2012, 76, DOI: 10.2136/sssaj2011.0390.

106. Bartley, R.; Goodwin, N.; Henderson, A.E.; Hawdon, A.; Tindall, D.; Wilkinson, S.N.; Baker, B. A comparison of tools for monitoring and evaluating channel change. Report to the national environmental science programme; Cairns, Australia, 2016. 
107. Civil Aviation Safety Authority. Flying drones/remotely piloted aircraft in australia. Available online: https://www.casa.gov.au/aircraft/landing-page/flying-drones-australia (accessed on 5/07/2017),

108. Jarihani, A.A.; Callow, J.N.; McVicar, T.R.; Van Niel, T.G.; Larsen, J.R. Satellite-derived digital elevation model (dem) selection, preparation and correction for hydrodynamic modelling in large, low-gradient and data-sparse catchments. J Hydrol 2015, 524, 489-506, https://doi.org/10.1016/j.jhydrol.2015.02.049.

109. Cunliffe, A.M.; Brazier, R.E.; Anderson, K. Ultra-fine grain landscape-scale quantification of dryland vegetation structure with drone-acquired structure-from-motion photogrammetry. Remote Sens. Environ. 2016, 183, 129-143, https://doi.org/10.1016/j.rse.2016.05.019.

110. Brodu, N.; Lague, D. 3d terrestrial lidar data classification of complex natural scenes using a multi-scale dimensionality criterion: Applications in geomorphology. ISPRS J Photogramm Remote Sens. 2012, 68, 121134, http://dx.doi.org/10.1016/j.isprsjprs.2012.01.006.

111. Jensen, J.; Mathews, A. Assessment of image-based point cloud products to generate a bare earth surface and estimate canopy heights in a woodland ecosystem. Rem. Sens. 2016, 8, DOI: 10.3390/rs8010050.

112. Serifoglu, C.; Gungor, O.; Yilmaz, V. Performance evaluation of different ground filtering algorithms for uav-based point clouds. Int. Arch. Photogramm. Remote Sens. Spat. Inf. Sci. 2016, 41, DOI: 10.5194/isprsarchives-XLI-B1-245-2016.

113. Dandois, J.P.; Ellis, E.C. High spatial resolution three-dimensional mapping of vegetation spectral dynamics using computer vision. Remote Sens. Environ. 2013, 136, 259-276, https://doi.org/10.1016/j.rse.2013.04.005.

114. Tonkin, T.; Midgley, N. Ground-control networks for image based surface reconstruction: An investigation of optimum survey designs using uav derived imagery and structure-from-motion photogrammetry. Rem. Sens. 2016, 8, 786, DOI: 10.3390/rs8090786.

115. James, M.R.; Robson, S. Mitigating systematic error in topographic models derived from uav and groundbased image networks. Earth Surf. Process. Landf. 2014, 39, 1413-1420, DOI: 10.1002/esp.3609.

116. Clapuyt, F.; Vanacker, V.; Van Oost, K. Reproducibility of uav-based earth topography reconstructions based on structure-from-motion algorithms. Geomorphology 2016, 260, 4-15, https://doi.org/10.1016/j.geomorph.2015.05.011.

117. Eltner, A.; Schneider, D. Analysis of different methods for $3 \mathrm{~d}$ reconstruction of natural surfaces from parallel-axes uav images. Photogramm. Rec. 2015, 30, 279-299, DOI: 10.1111/phor.12115. 